\title{
Cognition enhancers in age-related cognitive decline
}

Citation for published version (APA):

Riedel, W. J., \& Jolles, J. (1996). Cognition enhancers in age-related cognitive decline. Drugs \& Aging, 8(4), 245-274. https://doi.org/10.2165/00002512-199608040-00003

Document status and date:

Published: 01/01/1996

DOI:

10.2165/00002512-199608040-00003

Document Version:

Publisher's PDF, also known as Version of record

\section{Please check the document version of this publication:}

- A submitted manuscript is the version of the article upon submission and before peer-review. There can be important differences between the submitted version and the official published version of record.

People interested in the research are advised to contact the author for the final version of the publication, or visit the DOI to the publisher's website.

- The final author version and the galley proof are versions of the publication after peer review.

- The final published version features the final layout of the paper including the volume, issue and page numbers.

Link to publication

\footnotetext{
General rights rights.

- You may freely distribute the URL identifying the publication in the public portal. please follow below link for the End User Agreement:

www.umlib.nl/taverne-license

Take down policy

If you believe that this document breaches copyright please contact us at:

repository@maastrichtuniversity.nl

providing details and we will investigate your claim.
}

Copyright and moral rights for the publications made accessible in the public portal are retained by the authors and/or other copyright owners and it is a condition of accessing publications that users recognise and abide by the legal requirements associated with these

- Users may download and print one copy of any publication from the public portal for the purpose of private study or research.

- You may not further distribute the material or use it for any profit-making activity or commercial gain

If the publication is distributed under the terms of Article $25 \mathrm{fa}$ of the Dutch Copyright Act, indicated by the "Taverne" license above, 


\section{Cognition Enhancers in Age-Related Cognitive Decline}

Wim J. Riedel and Jellemer Jolles

Maastricht Brain and Behaviour Institute, Department of Psychiatry and Neuropsychology, University of Limburg, Maastricht, The Netherlands

\section{Contents}

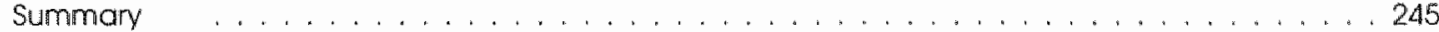

1. Patients and Experimental Models ... . . . . . . . . . . . . . . . . . . . . . . . . 248

1.1 Patient Populations . . . . . . . . . . . . . . . . . . . . . . . . . . 248

1.2 Experimental Models . . . . . . . . . . . . . . . . . . . . . . . . . . . . 248

2. Dependent Variables in Experiments and Clinical Trials . . . . . . . . . . . . . . 250

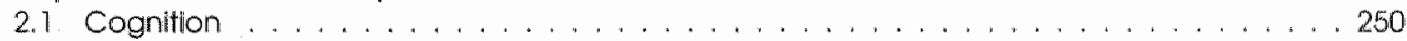

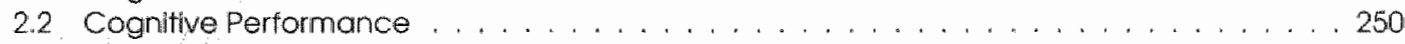

2.3 EEG Measures . . . . . . . . . . . . . . . . . . . . . . . . . . . . . . . . 251

2.4 Clinical Ratings . . . . . . . . . . . . . . . . . . . . . . . . . . . . . . . 251

3. An Overview of Cognitlon Enhancers in Single- and Multiple-Dose Studles . . . . . . . . . . 252

31 Nootropic Agents . . . . . . . . . . . . . . . . . . . . . . . . . . . . 252

3.2 Ergot Alkalolds . . . . . . . . . . . . . . . . . . . . . . . . . . . 253

3.3 Neuropeptides . . . . . . . . . . . . . . . . . . . . . . . . . 256

3.4 Cholinergic Agents . . . . . . . . . . . . . . . . . . . . . . . . . 257

3.5 Monoaminergic Enhancers . . . . . . . . . . . . . . . . . . . . . . . 259

3.6 GABA-ergic Agents . . . . . . . . . . . . . . . . . . . . . . . . . . . . 261

3.7 Aminoacidergic Regulators . . . . . . . . . . . . . . . . . . . . . . 261

3.8 Methylkanthines . . . . . . . . . . . . . . . . . . . . . . . . . . . . . . . 262

3.8 Vltamins . . . . . . . . . . . . . . . . . . . . . . . . . . . . . . . 262

3.10 Herbal Compounds . . . . . . . . . . . . . . . . . . . . . . . . . . . . . 263

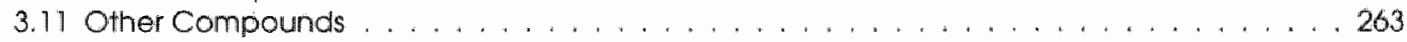

4. Discussion . . . . . . . . . . . . . . . . . . . . . . . . . . . 265

4.1 The Patient Population as a Target for Drug Studies . . . . . . . . . . . . . . . . 265

4.2 Methods Used for Treatment Evaluation . . . . . . . . . . . . . . . . . . . . . . 266

4.3 Future Possibilities . . . . . . . . . . . . . . . . . . . . . . . . . . 267

5. Concluding Remarks . . . . . . . . . . . . . . . . . . . . . . 268

Summary
A review of recently published studies on the effect of cognition enhancers in non-demented human study participants is presented. The heterogeneity of the therapeutic target, age-associated cognitive decline, can be improved by separately treating groups in whom age-extrinsic factors may underlie cognitive pathology. Standardisation of cognitive assessments is necessary, since many different tests are applied to answer the same question. Modelling cognitive dysfunction, either by pharmacological or nonpharmacological means, in humans is highly recommended since it allows hypotheses to be tested in a clearly oper- 
ationalised way. Predictive validity of the currently applied models for the clinical situation remains a problem, however. The scopolamine (hyoscine) model has, to a reasonable extent, predictive validity for the cholinergic agents.

The results of 67 single-dose studies and 30 multiple-dose siudies are summarised. All single-dose studies and 14 multiple-dose studies were carried out in young or elderly human volunteers. In 45 of 81 volunteer studies, models of cognitive dysfunction were employed. The scopolamine model was the most used $(\mathrm{n}=21)$; the other studies induced cognitive dysfunction by means of benzodiazepines (8), hypoxia (7), alcohol (5) and sleep-deprivation (4). The remaining 16 multiple-dose studies were clinical trials of a duration varying between 2 weeks and 1 year (average duration was 14 weeks). In these trials, the effects of cognition enhancers were assessed in elderly people in whom impairment of memory, psychomotor performance or cognitive function was determined. These included age-associated memory impairment (AAMI) and ageassociated cognitive decline (AACD).

There were many studies in which the cognition enhancing properties of substances in humans were reliably demonstrated. The cognition enhancing properties of substances that are widely used, such as caffeine, nicotine and vitumins, may already be active against AACD. New developments such as serotonin (5hydroxylryptamine $3 ; 5-H_{3}$ ) antagonists and $N$-methyl-D-aspartate (NMDA) antagonists have provided marginal and disappointing results in AAMI. There is no cognition enhancer that has reliably and repeatedly been demonstrated to be efficacious for the treatment of AACD. However, this situation may change as the selectivity, specificity and adverse effect profiles of substances that are being developed for the treatment of $\mathrm{AD}$ may be expected to be improved in the future.

Cognitive aging, or age-associated cognitive decline (AACD), is a phenomenon that is characterised by the decline of many aspects of cognitive functioning with age. ${ }^{[1]}$ " There is, however, a considerable variability between individuals as to the rate of cognitive decline. Not only does the physiological aging process influence cognition in the elderly, but also various biological factors such as medical conditions.

There is a borderline between so-called 'normal cognitive aging' and pathological conditions such as dementia, notably Alzheimer's disease (AD), involving disorders of memory and other cognitive functions ${ }^{\text {[s] }}$ Dementia and related pathological conditions, including prodromes of dementia, have a great impact on society because of the financial and organisational consequences for both family

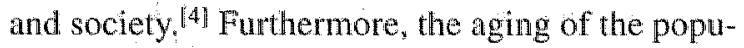
lation results in an increasing prevalence of $A A C D$, and a widespread request for therapeutic agents aimed at least at improving the conditions of cognitive impairment or halting cognitive decline. .6,7| $^{6}$

Unfortunately, although great progress has been made in our understanding of mechanisms of drug action in the brain, and in our understanding of brain changes in elderly people with cognitive deficits or AD patients, a breakthrough in the treatment of these conditions does not seem to be at hand.

Yet, there has been apid increase in the interest of clinicians, researchers and the pharmaceutical industry in the development of new classes of drugs designed especially for palliative treatment of AACD and AD-related conditions. ${ }^{[8-10]}$ As a consequence, the number of putative cognition enhancing agents (nootropics) presently under preclinical and clinical investigations is exceedingly high. Hundreds of pharmacological compounds have been developed and tested for their effects on memory in animals, healthy volunteers and AD patients. [11-13]

A problem facing research into the clinical de- 
velopment of cognition enhancers is that $A A C D$ is not recognised as a disease. No consensus exists as to whether AACD actually should be a therapeutic target for cognition enhancers. ${ }^{[14]}$ The same compounds have been tested in AD patients, govermed by the hope that once a drug is tegistered for that disease, the next step would be to apply it to the treatment of AACD. "I5" Furthermore, the questions of whether dementia is the end-point, and $\mathrm{AACD}$ or brain aging is the prodrome, are still open. $[16]$

Although the incidences of both AD and AACD are increasing, the latter accounts for a far larger proportion of the population, and in the last decade of the twentieth century the number of persons over 65 years of age will double. AACD has recently become a diagnostic entity in DSM-IV $[17]$ and therefore it is likely that the interest in the pharmacological treatment of this condition will revive.

Nootropic properties of drugs were first defined in 1972 by Giurgea ${ }^{[18]}$ as enhancement of learning and memory, facilitation of intercallosal transfer, neuroprotection and a lack of adverse effects. Given this profile, the primary target groups for nootropic treatment consisted of the elderly and people with dementia. Since then, many substances have been developed with the same aim, but they do not fulfil the above definition of nootropic drugs. These are therefore called cognition enhancers, which are defined primarilly in terms of their effect. Cognition enhancement can also be achieved by psychostimulants and antidepressant drugs, but we do not refer to these as cognition enhancers as this is not their most characteristic feature.

Nowadays, the term nootropic drugs usually refers only to the piracetam-like compounds which contain the 2-oxopyrrolidineacetic acid derivative (racetam) substructure. [19]

In the past 5 years, numerous controlled experiments and clinical trials in demented, but also in non-demented, physically healthy humans, young and old, with or without AACD, have been conducted. Excellent updates, summarising most of the modern research in cognition enhancers in an- imals ${ }^{[12,20]}$ and in patients suffering from $A D,[13,21]$ have recently been published.

Sarter and colleagues ${ }^{[2,20]}$ explained difficul. ties that have energed in the search for drugs to enhance cognitive performance in patients with dementia and in aged individuals. A systematic and rigorous evaluation of validity (predictive, face and construct) for the animal models most frequently used in preclinical research, was deemed a necessary prerequisite for further research. Giacobini and Becker ${ }^{21]}$ categorised putative cognition enhancers for the treatment of $\mathrm{AD}$, into the following groups:

- drugs that survived (cholinesterase inhibitors);

- drugs that revived (muscarinic agonists);

- drugs that never made it (nootropics, cholinergic function enhancers, acetylcholine releasers and modulators, neuropeptides, and hormone precursors and growth factors);

- unfulfilled promises (calcium uptake blockers or antagonists, glutamate agonists/antagonists, antioxidant compounds and anti- $\beta$-amyloid drugs); and

- winner drugs (second- and third-generation cholinesterase inhibitors with higher selectivity and specificity).

We have attempted to review the results from controlled experiments and clinical trials with cognitive enhancers in humans without dementia that have been published since 1990 . Two general questions governed the review process. The first question was the cognition enhancers' proof of existence: do they work? - i.e. do cognition enhancers indeed enhance cognition? The second question addressed the search for underlying (brain) mechanisms: if cognition enhancers work, how do they work? In this paper; we can translate the latter question into: which particular compounds work more than others, as specified in terms of the mechanism that they manipulate?

In section 1, the patient groups, from healthy young volunteers to elderly patients with memory complaints or cognitive disorders, are described. A distinction is made between experiments performed under normal conditions and experiments 
performed under conditions intended to model AACD. In section 2, the dependent measures used in most studies, cognitive and psychomotor tests, clinical and psychophysiological lelectroencephalogram (EEG)] assessments, are briefly described. In section 3 , a review of studies whose primary aim was to investigate the claim of substance-induced cognition enhancement in individuals without dementia is presented.

This was accomplished by performing literature searches in the various relevant journals themselves as well as their abstracts published on $M e d-$ Line, PsycLit and Excerpta MedicalEmbase from 1990 until March 1995. As far as possible, abstract books of congresses covering the subject matter were searched for relevant contributions, and our own nonsystematic exposure to knowledge about experiments and trials with cognition enhancers was utilised. In the last 2 sections, discussion and concluding remarks respectively, the results are put into perspective.

\section{Patients and Experimental Models}

\section{1 Patient Populations}

In our previous paper on cognitive impaiment in elderly people, ${ }^{[4]}$ several concepts, such as benign and malignant senescent forgetfulness, [22] age-associated memory impairment (AAMI), 231 late-life forgetfulness and age-consistent memory impairment, ${ }^{124]}$ were described in an effort to identify the arget population of elderly people with cognitive aging. Since the proposal of the criteria for AAMI, ${ }^{23}$ this has been the most used description, particularly in drug trials. However, according to some of the many criticisms, ${ }^{[8,24-28]}$ the AAMI criteria classify some $67 \%$ of the population over 50 years of age as having this disorder. Recently, stricter criteria for the condition AACD have been published. $[17\}$

Other populations which have been studied may be described by:

- elderly patients with impaired cognitive function:[29]
- elderly patients with pronounced memory problems of unknown origin

- elderly deficient drivers; [31,32] $^{3}$

- memory-disturbed patients; $[33]$

- elderly patients with mild to moderate memory impairment according to NINCDS-ADRDA criteria. $[34-36\rceil$

These are variations on the same theme, albeit that the first 2 seem to include more severe cases and hence truly constitute the borderline between normal and pathological aging.

Furthermore, some studies have been published on the effects of cognition enhancers in other neuropsychological populations, such as patients with epilepsy, organic brain syndrome after prolonged exposure to organic solvents or after alcoholism, in which alleviation of cognitive dysfunction was the prime target of drug therapy.

Many studies have been conducted on the effects of cognition enhancers in volunteers; these can be subdivided into those conducted in the young and the elderly. The rationale behind studying the effects of cognition enhancers in healthy ellderly volunteers does not differ very much from that of studying cognition enhancers in patients with AAMI. It is often assumed that normal elderly volunteers are also affected by, but not necessarily suffering from, cognitive aging. In addition, studies of cognition enhancers in elderly volunteers yield the pharmacokinetic and tolerability data appropriate for that age group.

In most of the studies into the effects of cognition enhancers in healthy young volunteers, specific experimental manipulations or paradigms are applied to induce aspects of cognitive dysfunction.

\subsection{Experimental Models}

Understanding AACD and treating it pharmacologically calls for the wish to be able to model its presumed mechanism and hence predict the therapeutic response of putative cognition enhancers. Several human models have been the subject of debate, particularly the scopolamine (hyoscine), benzodiazepine and hypoxia models of cognitive dysfunction. [37-39] 
The major problem in predicting clinical efficacy from human experimental results and phase I data is the lack of resemblance between the models used and the clinical condition. This problem is complicated by the diversity of the potential mechanisms of action of new compounds. A further question is whether phase I studies should be used as predictors of clinical efficacy at all. It has nonetheless been suggested that some human models. (e.g. scopolamine-induced amnesia, hypoxiainduced performance deficits) are indeed potential predictors of clinical response. ${ }^{381}$ These models have, in the past 5 years, frequently been used in the process of screening the effects of cognition enhancers in humans.

\subsubsection{The Scopolamine Model}

Deterioration of cholinergic system functioning has been postulated to contribute to memory impairment in normal aging and $\mathrm{AD}$. $^{[40,41]}$ The anticholinergic drug scopolamine, which acts by blocking muscarinic acetylcholine receptors, has been used to study the role of acetylcholine in attention and memory and to model aspects of the memory and other cognitive changes that occur with aging. ${ }^{[42-46]}$ Scopolamine-induced cognitive dysfunction, which consists largely of memory dysfunction, has been shown to be reversible when drugs stimulating the cholinergic system are administered concomitantly. ${ }^{[47-50]}$ However, this effect is not always found with CNS stimulants,, $51-54]$ which is another indication that anticholinergic effects are specifically related to impaired memory function.

\subsubsection{The Benzodiazepine Model}

Anterograde amnesia is a well-known adverse effect of the benzodiazepines. ${ }^{[55]}$ These transient drug-induced effects have been related to clinical attentional and memory deficits, ${ }^{[56]}$ and to dementia. ${ }^{1571}$ Amnesia caused by benzodiazepines may provide a useful model for some organic amnesias and thereby allow strategies to be developed for treating these amnesias. ${ }^{[58]}$ Furthermore, the rationale has been proposed that $\beta$-carbolines with antagonist or partial inverse agonist properties at the $\gamma$-aminobutyric acid (GABA) benzodiazepine re- ceptor complex may offer a treatment for senile dementia. ${ }^{[57]}$

\subsubsection{The Hypoxia Model}

The CNS is particularly sensitive to hypoxia with resultant demonstrable effects on cognitive function. ${ }^{[59]}$ Most models of hypoxia and ischaemia are used for evaluating the metabolic consequences of cerebral insult. ${ }^{[60]}$ They have also been used for inducing cognitive disturbance. ${ }^{1611}$ The pathological cascade atter severe hypoxia or ischaemia includes decreased ATP and influx of $\mathrm{Ca}^{++}$ and $\mathrm{Na}^{+}$with decrease in intracellular $\mathrm{K}^{+}$, leading to depolarisation, release of glutamate, noradrendline and acetylcholine, changes in neuronal plasticity, cell death and cognitive impairment. ${ }^{162}$ Possible pharmacological mechanisms for protecting brain function include blockade of $\mathrm{Ca}^{+4+}$ influx, inhibition of cell swelling, regulation of membrane potential, inhibition of neurotransmitter release and inhibition of excitatory amino acid recepcors. ${ }^{[62]}$

\subsubsection{Acute Ethanol Intoxication}

The behavioural toxicity of alcohol in humans is characterised by impaired performance on a great number of cognitive tasks. ${ }^{[6,3]}$ Alcoholinduced memory deficits have been claimed to mimic age-related memory deficits because of their functional similarity as to the state of depleted processing resources. 1641 The central effects of atcohol have also been said to be mediated through the GABA system and hence to resemble those of benzodiazepines. ${ }^{165}$ Furthermore, alcohol may induce histotoxic (as opposed to hypoxic) hypoxia since it reduces the oxygen uptake of lissue cells. ${ }^{[66]}$

\subsubsection{Sleep Deprivation}

Functional similarities have been postulated between AACD and sleep deprivation, and also that memory deficits in these conditions are more likely to occur in tasks which require a lot of thought rather than automatic processes. ${ }^{[64]}$ Lowering arousal, by means of sleep deprivation, is a frem quently used task manipulation in order to induce depletion of cognitive processing resources. [67] 
The decline in cognitive performance during sleep depriwation has been shown to be mediated by brain catecholamines. ${ }^{\mid 6: 8} \mid$

\section{Dependent Variables in Experiments and Clinical Trials}

\subsection{Cognition}

Observable behaviour as a function of physical stimuli, interconnected by an unobservable 'black box', was roughily the psychology of the behaviourists. Nowadays, psychology is the science of cognition, the black box between stimulus and response. Cognition is the label for all processes that mediate nonreflexive behaviour in living organisms.

The central theme of cognitive psychology is that of the organisms ' internal representation of the outside world. ${ }^{[69]}$ For example, novice and experienced clinicians differ in the way they perceive their patients and subsequently form their diagnoses. The explanation is not that their perception is different, but their internal representation of the problem, to which their perception is compared, differs.

The cognitive explanation is that perception, judgement, decision and overt response are governed by expectations, based on prior knowledge and experience, ${ }^{[70]}$ Thus, an internal representation cannot exist without memory. Perceived images are stored in working or short term memory and compared with knowledge retrieved from long term memory. Although memory is known to reside in the brain, it is certainly not one observable organ, but its vital functions, such as storage, search, consolidation and retrieval, can be assessed using neuropsychological tests, EEG measures, clinical ratings or elaborate computerised methods.

The vulnerability of memory is illustrated by the gradual, but in the end complete, distuption of this cognitive system in patients with dementia. It is therefore logical that most trials investigating the efficacy of cognition enhancers primarily aim to assess improvements of memory functions.

\subsection{Cognitive Performance}

There is no uniformity in the test procedures or experimental tasks to evaluate the efficacy of cognition enhancers. "71] The way in which memory processes or cognitive functioning has been operationalised differs amongst the studies.

The most frequently used procedure is word list learning. The relevance of a word learning task for cognitive pharmacology is that this task provides the possibility to examine the effectiveness of retrieval strategies. As such, the multi-trial free recall procedure is a powerful paradigm to examine verbal memory processes. ${ }^{[72]}$

Unfortunately, as in the presentation of word list learning procedures, standardisation has been lacking. Some studies only refer to the word list learning procedure without specification of how many words were used or how often the list of words was presented. Specification of procedures such as delayed recall and delayed recognition was often lacking. Some studies did report the number of words in the list, but no information was given about whether parallel hists were used. Some studies explicitly reported the use of the Rey AuditoryVerbal Learning Test, ${ }^{[73]}$ a standardised procedure, while others only mentioned the use of a 15-word learning test, without further specification.

The evaluation of drug effects over studies is thus hindered by the lack of uniformity in the procedures used. The number of words per list, the rate of presentation, the retention interval, the number of monosyllables versus bisyllables, the frequency of the words in the native language and other variables also vary across studies.

A well-defined procedure which differs from the Rey procedure is the Buschke's Selective Reminding Method. ${ }^{174]}$ In this procedure, parallel lists are used, consisting of 15 related nouns. The patient has to recall the list within 1 minute. Nouns that are left out by the patient are read asain by the experimenter. This is done repeatedly for 10 trials (but less in many studies). The procedure provides information about short term memory, long term memory and the retrieval strategy. 
Another frequently used test of visual memory is the Benton Visual Retention Test. The test, however, has been subject to criticism, because it is not very sensitive. Moreover, it is disputed that the test measures immediate visual memory and the notion is supported that it is a test of visuomotor performance. ${ }^{[71]}$

The second most important paradigm in memory assessment is perhaps the well known Sternberg paradigm, in which the speed of retrieval from short term memory is measured. ${ }^{[75]}$ This is accomplished by instructing the patient to compare new stimuli with target stimuli held in short term memory (memory set). By repeating the tests while increasing the memory set, measures reflecting the speed of scanning 1 item in short term memory are obtained separately from the offset speed component of the task, which is not memory-related. This task has been shown to be very sensitive to aging. ${ }^{176]}$ Noncomputerised versions of this principle are also available. The task is interesting because it allows separate estimates, obtained in 1 test, of speed of memory- and non-memoryrelated information processing. [77]

The operation of the different aspects of memory is poor in most studies investigating cognition enhancers. Testing has been done with numerous different procedures. Standardisation and a description of the procedures are often lacking. Testing procedures from experimental psychology should be used when aspects of memory processes would be better suited to assess the underlying biological mechanisms. Standardised procedures of memory testing with well-evaluated parallel test versions can be regarded as an essential prerequisite for an experimental study into the efficacy of a cognition-enhancing drug.

\subsection{EEG Measures}

A distinction must be made between EEG assessed at rest, the so-called background EEG, and task-related measures such as those obtained using the event-related potentials (ERP) paradigm, of which the P300 is the most used. The latter seem to be more important, since changes in EEG activ- ity when patients are at rest point primarily to changes in vigilance and not necessarily cognition. Nevertheless, background EEG-measures after the administration of cognition enhancers are used quite often, especially applied in models of cognitive dysfunction. The background $\mathrm{EEG}$ has been used in a number of trials primarily with the aim of assessing the brain bioavallability of cognition enhancers, and also offers the possibility of evaluating the distribution of changed activity over the different regions of the cortex. $[7$ is]

Brain imaging techniques which yield quantitative measures of regional brain function (or metabolism), such as positron emission tomography (PET) and single photon emission computerised tomography (SPECT), may be superior at determining the location in space (i.e. where in the brain) of drug-induced changes. Task-related EEG measures, ERPs, are superior in terms of location in time (i.e. speed of cognitive processing) of druginduced changes. The P300 is perhaps the best measure of drug-induced changes in cognitive processes in the brain, as compared with measures of cognitive test performance which are the endproducts of those processes.

\subsection{Clinical Ratings}

Some investigators have evaluated efficacy with the help of clinical rating and mood scales, such as the Mini-Mental State Examination or the Sandoz Clinical Assessment-Geriatric. The true end-products of all cognitive and noncognitive processes are reflected in clinical rating scales. The most typical of these is the Clinical Global Impression, which reflects the judgement of the clinician about a patient's mental status, expressed on a scale of 1 to 7 . Although the title of the scale suggests that it is always the clinician who performs the ratings, subjective ratings by the patient are also included, and there is a growing number of trials in which ratings of the partners or carers of the patients are used as primary measures of outcome.

An important development in clinical trials of $A D$ is the 'Clinician's Interview-Based Impression of Change' (CIBIC). It is doubtful whether this 
measure would be sensitive in AACD. Applied in placebo-controlled double-blind drug trials, however, these ratings can, in general "be sensitive but highly nonspecific indicators of drug effects. [15]

Chinical rating scales are generally seen as the counterbalance against the often heard criticism that cognitive performance tests as well as $\mathbb{E E G}$ measures yield, at most, microscopic changes that can never been seen through the naked eye. This phenomenon is most obviously present in clinical research in $A D$ patients, where, even though the claim of $\mathrm{AD}$ being a memory or cognitive disease is still always made, clinical assessments are far more important than any of the cognitive or process measures.

\section{An Overview of Cognition Enhancers in Single- and Multiple-Dose Słudies}

The results of experiments and clinical trials with cognition enhancers in humans without dementia can be categorised along several dimensions, such as population studied, type of drug, dosage used and cluration of the study. We chose to make a distinction between 67 single-dose studies and 30 mulliple-dose studies, which are listed in tables 1 and $I_{\text {, }}$ respectively. All studies are at least single-blind and controlled with placebo or an active drug.

Nearly all single-dose studies were carried out in healthy volunteers. In 45 of the volunteer studies, models of cognitive dysfunction were employed. The scopolamine model was the most used $(\mathrm{n}=21)$, while the other studies induced cognitive dysfunction by means of benzodiazepines (8), hy poxia (7), alcohol (5) and sleep deprivation (4). Most multiple-dose studies were carried out in elderly people, volunteers $(n=10)$ and patients $(20)$, with cognitive impairment.

The main modes of action of the classes of cognition enlwancers studied are described below, as well as the major results obtained from the multiple-dose studies.

\subsection{Nootropic Agents}

Even recent reviews of piracetam and related compounds state explicitly that, in spite of a tremendous amount of research in the latter 30 years, no commonly accepted mechanism of action has been established. ${ }^{[19,151]}$ Some benefit of piracetamlike nootropics in clinical studies of patients with mild to moderate degrees of dementia has been demonstrated, although the clinical response is estimated to lie in the 10 to $30 \%$ range. ${ }^{[152]}$ The possible modes of action of nootropic drugs can be grouped in 4 categories: (152)

- Effects on energy metabolism, such as increased adenylate kinase activity and increased glucose utilisation in hypoxic and anticholinergic conditions.

- Effects on cholinergic mechanisms, such as increased high-affinity choline uptake and increased density of cottical muscarinic receptors.

- Effects on excitatory amino acid receptormediated functions, such as increased hippocampal glutamate release and potentiation of the AMPA-induced calcium influx by means of AMPA receptor stimulation.

- Steroid sensitivity, which was shown by the absence of nootropic effects in adrenalectomised animals and by the blockade of nootropic effects by pretreatment with steroid hormones.

After 30 years, there are still new results published about the effects of piracetam and its successors. A clinical trial in individuals without dementia with mild to moderate memory impairment yielded positive effects for piracetam 3 and $6 \mathrm{~g} / \mathrm{day}$ on tests of attention and memory, and also cllinical improvement. ${ }^{[3]}$ An interesting combination of treatment with piracetam 2.4 and $4.8 \mathrm{~g} /$ day with memory training therapy showed that combined therapy was most effective with the $4.8 \mathrm{~g} /$ day dose in patients whose baseline performance on memory tests was lowest. ${ }^{[131]}$ Despite the intriguing combination of drug treatment with a memory training programme, it must be noted here that a post hoc split-half analysis in order to evaluate treatment effects is a dubious practice which invalidates the analysis. 
The 2 studies of piracetam $4.8 \mathrm{~g} /$ day on the ability of deficient elderly drivers to perform tests of car driving in real traffic ${ }^{[31,32]}$ were, in this sense, more adequate. In both studies, elderly people were selected on the basis of objectively assessed deficits in psychomotor performance. In the first study, selection was based on psychomotor test performance below the median of the age reference group. This study showed that piracetam treatment reduced the number of errors made in real traffic, compared with placebo treatment. ${ }^{[31]}$

In the second study, elderly patients were selected on the basis of "deficient" performance in 1 established driving test in real traffic and scoring below the median on another. This study showed. no beneficial effects of piracetam on car driving performance. However, enhanced postural stability after piracetam showed that the drug was aclive. 132$]$

If drugs improve postural stability, there is evidence that the central availability of cognitive processing resources is supplemented, ${ }^{[153,154]}$ and hence cognitive enhancement could be the result. Such a hypothesis seems prominent in the case of the piracetam-like drugs and could very simply be tested by having the patients" cognitive performance tested in a standing position while simultaneously measuring their postural stability. However, this has never been done to our current knowledge. There is some evidence that the more recently developed drugs in this category, such as pramiracetam, are more potent and perhaps more efficacious.

In 1991, a review of the therapeutic use of piracetam in senile cognitive disorders concluded that the clinical usefulness of the drug was the subject of much debate because it continued to give mixed results. ${ }^{[51]}$ In the light of what is presented here, this does not appear to have changed.

Pramiracetam $600 \mathrm{mg}$ administered twice daily during a 12-week period to elderly patients with memory impairment led to significant improvements in memory performance relative to placebo. [34] Pramiracetam 600mg administered twice daily during a period of 10 days, when compared with placebo, was able to partially reduce the amnesic effects induced by scopolamine both in young ( 18 to 42 years) and elderly (55 to 65 years) patients. $1132 \pi$

\subsection{Ergot Alkalloids}

Ergot alkaloids exert direct action at $\alpha$ adrenergic, dopamine and serotonin receptors. They appear to have a normalising effect on central monoaminergic neurotransmitter systems; compensating for both hyperactivity and deficits of the adrenergic, serotonergic and dopaminergic systems. Ergot alkaloids have marked pre- and postsynaptic a-adrenoceptor antagonist activity, with higher affinity for $\alpha_{2-}$ than $\alpha_{1}$-receptors, and mixed agonist/antagonist effects at dopamine $\mathrm{D}_{1}$ and $\mathrm{D}_{2}$ receptors and at serotonergic $\left(5-\mathrm{HT}_{1}\right.$ and $5-\mathrm{HT}_{2}$ ) receptors. ${ }^{1155]}$

Ergoloid mesylates (codergocrine mesylate) is a combination of the mesylated forms of dihydroergocornine, dihydroergocristine, dihydro- $\alpha$-engocryptine and dihydro- $\beta$-ergocryptine. In a double-blind placebo-controlled trial using the hypoxia-model, a single dose of ergoloid mesylates $5 \mathrm{mg}$ administered to 12 healthy young volunteers significantly attenuated hypoxia-induced brain dysfunction and psychometric performance $|84|$ In a similar subsequent trial, further augmentation of the severity of hypoxia resulted in a loss of brain protection, even when ergoloid mesylates was given daily over 2 weeks. ${ }^{[84]}$

A review of the results from controlled studies of elderly patients with AACD established that, in some studies, ergolloid mesylates had statistically significant positive effects on symptoms of cognitive dysfunction. Nevertheless, the specific place of ergoloid mesylates in the treatment of agerelated cognitive decline remains undetermined, despite many years of clinical use ${ }^{(155)}$

The central bypothesis underlying the cognition enhancing properties of the ergot alkaloids is that of improved brain perfusion. Notwithstanding the fact that there is at least some evidence of a weak effect of the drug, there is no clinical study that clearly confirms the cognition enhancing effects 


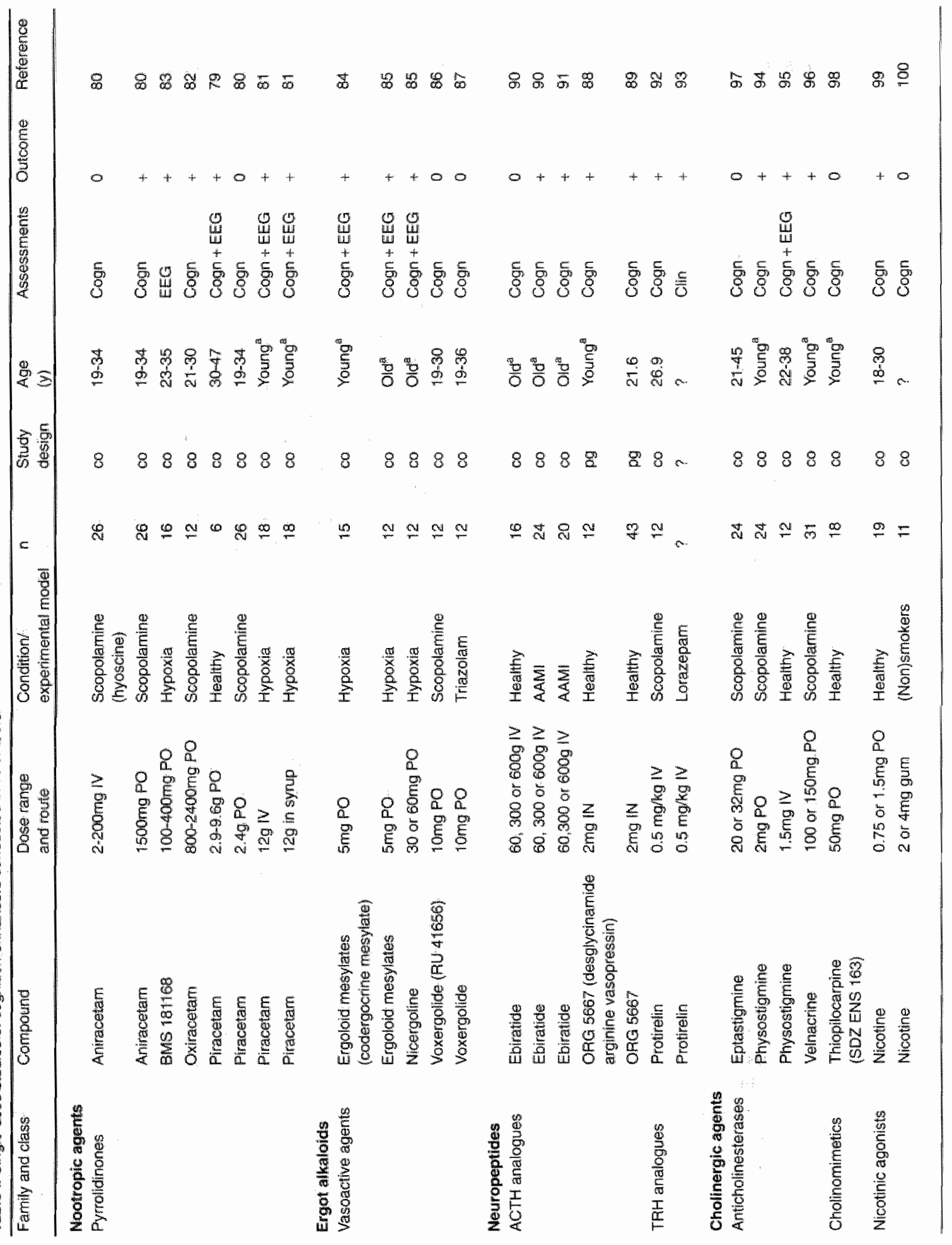




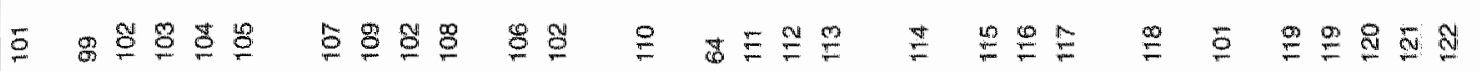

昰

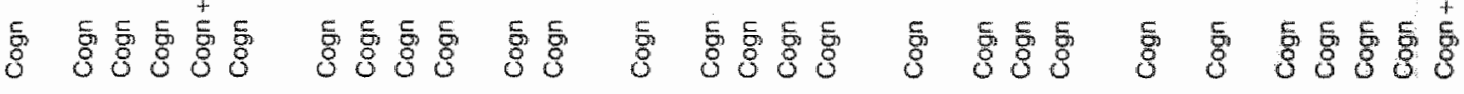

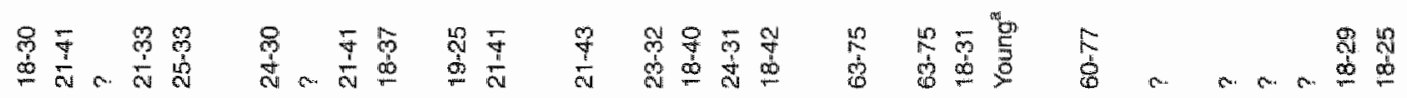

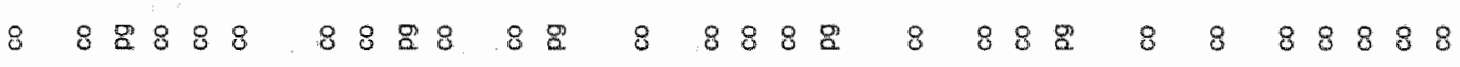
웅

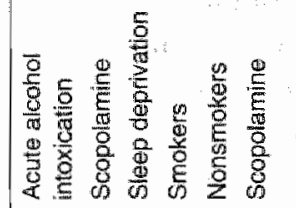
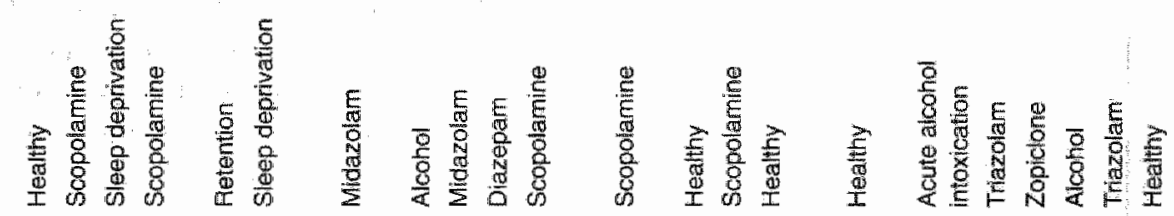

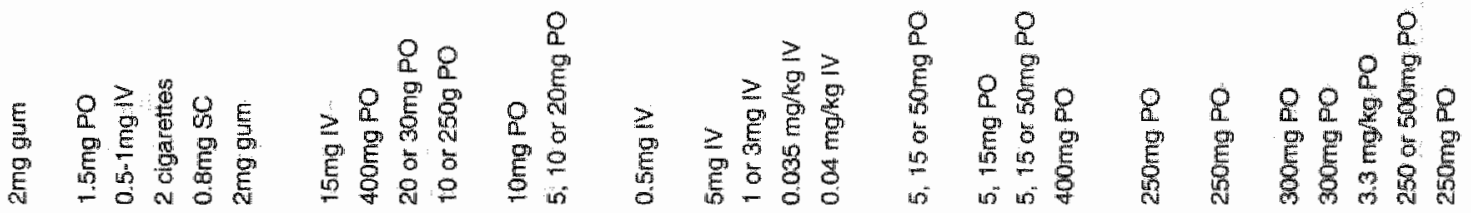
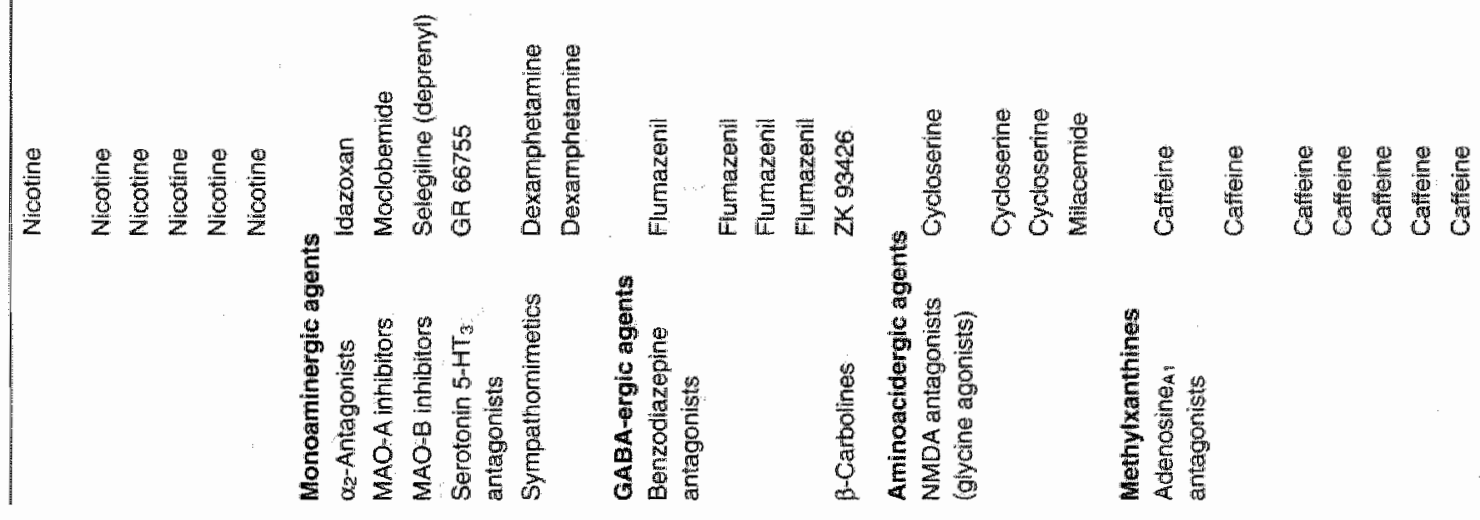


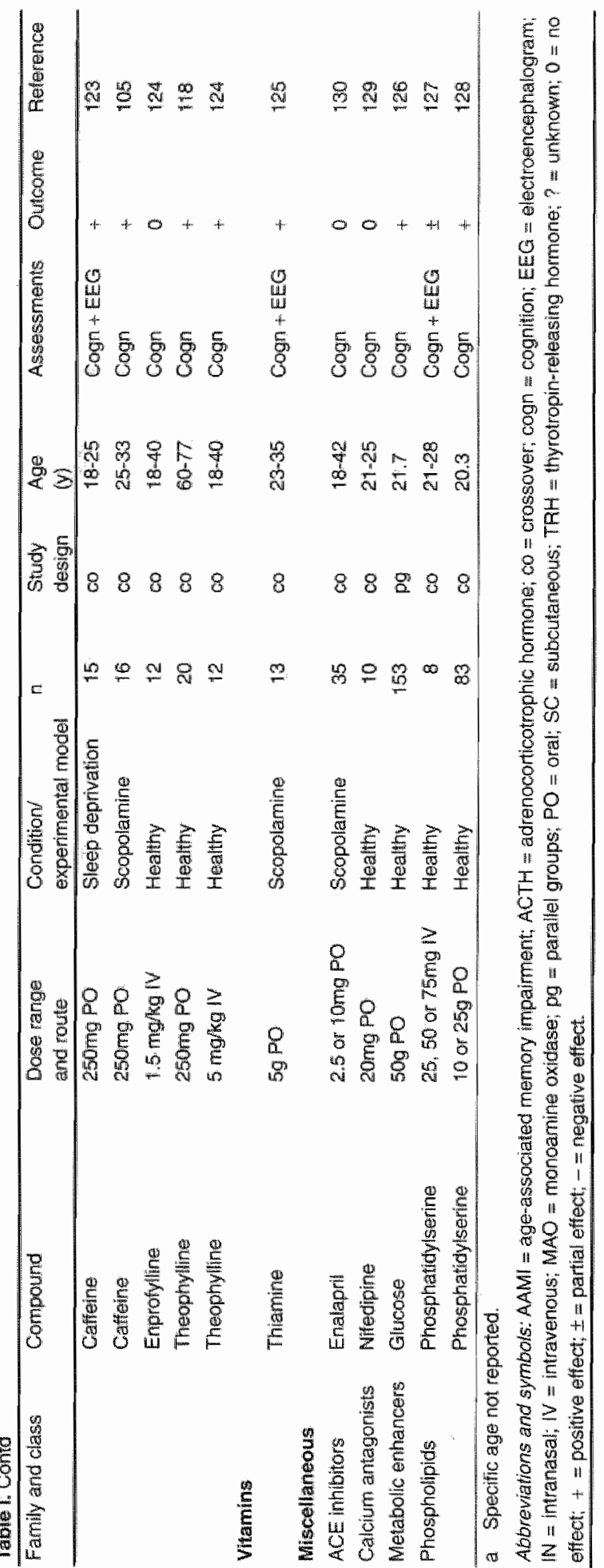

simultaneously with the assessment of improved brain perfusion.

Several examples of protection by an ergot alkaloid against disturbed brain perfusion using the hypoxia model were obtained from single-dose studies. The study that addressed this problem in perhaps the best possible way, by applying the hypoxia model at the end of subchronic treatment with ergoloid mesylates, did not show the desired effect. $[84]$

\subsection{Neuropeptides}

Several neuropeptides, namely adrenocorticotrophic hormone (ACTH) and thyrotropin-releasing hormone (TRH) analogues, have been shown to exert significant effects on motivational, learning and memory processes. ${ }^{[1]}$ The effects of corticotrophin (exogenous ACTH) appear to be independent of its endocrinological action on the adrenal contex.

Neuropeptides related to the pituitary hormone vasopressin have also received profound interest. ${ }^{[156]}$ A series of 5 consecutive clinical trials was published in which the neuropeptide ORG 5667 (desglycinamide arginine vasopressin; DGAVP) was administered to 64 parients with cognitive and memory complaints. The patients selected for the study were carefully screened with the aid of neuropsychological assessment procedures. The trials were conducted according to a structured design in which the variables "dose", "route of administration", "treatment schedule", "diagnostic group" and 'severity of deficit' were altered from trial to trial in order to find optimal conditions for the possible expression of a peptide effect.

The results indicated a statistically significant effect of ORG 5667 on word list learning in patients with mild brain trauma, suggesting that learning performance and memory retrieval were improved after peptide treatment in these patients. Some effects of ORG 5667 , e.g. increased speed of memory search, were observed in patients with age-associated memory deficits. ${ }^{[33}$ ERPs were recorded in 22 elderly and 28 young patients who received $101 \mathrm{U}$ of argipressin (arginine vasopressin) 
intramasally 22,12 and 1 hour(s) prior to experimental sessions. The results indicated that argipressin improved ERP signs of stimulus processing associated with attentional mechanisms. However, the ERP signs of AACD remained unimproved after argipressin. [133]

\subsection{Cholinergic Agents}

The cholinergic hypothesis of geriatric memory dysfunction entails that cognitive decline can be counteracted by enhancement of central cholinergic function. ${ }^{[40]}$ This hypothesis has stimulated interest in cholinergic function of the brain in relation to human cognition and AACD. It is unclear whether nomal aging results in a loss of cholinergic innervation to cerebral cortex and hippocampus, as in $\mathrm{AD}$, but the prevailing evidence suggests that certain aspects of brain cholinergic function ane diminished with advancing age. [157]

Cholinergic receptors in the brain are of the muscarinic and nicotinic type and there are muscarinic and nicotinic agonists that stimulate these 2 subtypes of acetylcholine neurotransmission. Selective compounds that are specifically aimed at muscarine $m_{1}$ receptor subtypes have been developed and these represent a new avenue in the treatment of AD. Studies in humans have been reported to show the selectivity and specificity of these agents but, unfortunately, reports on their cognitive effects in humans are lacking. ${ }^{158]}$ The main development in nicotinic agonists is reflected by the interest in the influence of nicotine on cognition, $[159.160]$

An additional therapeutic avenue is to use precursors of acetylcholine to increase the symthesis of acetylcholine in the brain. Cholinesterase inhibitors increase acetylcholine neurotransmission by means of inhibiting the activity of the emzymes that normally degrade acetylcholine. Cholinesterase inhibitors are currently in the focus of interest since tacrine was approved for use in the treatment of dementia of the Alzheimer type, the first drug to be registered for this purpose. [16"] This has stimulated research with cholinergic agents in general and cholinesterase imhibitors in particular; second and third generations of these compounds are currently being studied and developed. ${ }^{162}$ Because of their adverse effect profile, these agents are perhaps less interesting in relation to the treatment of $\mathrm{AACD}$, but the results obtained in phase 1 studies with healthy volunteers are interesting from a theoretical and methodological point of view.

The influence of 4 weeks' treatment with the cholinesterase inhibitor huperzine A 200 to 400 $\mu \mathrm{g} / \mathrm{day}$ on memory complaints when administered to 101 patients with benign senescent forgetfulness was found to be superior to that of piracetam 2.4 to $3.2 \mathrm{~g} / \mathrm{day}$. 1341 The effects of repeated doses of linopirdine $20 \mathrm{mg}$ (a phenylindolinone derivative enhancing the release of acetylcholine in cholinergic nerve terminals) administered twice a day over a 10-day period were investigated in 30 elderly men. EEG showed significant central effects of linopirdine, indicative of an improvement in vigilance. [135]

The relative success of chalinesterase inhibitors as a palliative treatment in $\mathrm{AD}$ is not so apparent in AACD. A high incidence of adverse events, particularly hepatotoxicity, combined with relatively few possibilities for cognitive improvement, has led to a negative cost-benefit ratio of these agents in AACD. This situation could change if secondand third-generation cholinesterase inhibitors developed for the treatment of $\mathrm{AD}$ lack the adverse event profile that is characteristic of tacrine! 161$]$ This seems to be the case for huperzine A, ${ }^{134]}$ but more data demonstrating the efficacy of the drug need to be gathered.

Experiments using the scopolamine model of cognicive dysfunction have shown that cholinesterase inhibitors can completely reverse cholnergic deficits in humans, whereas the influence of most other substances tested using this model are reported in terms of a significant attenuation. If a substance shows no effect in the model, its devel.opment, all least in the doses studied, should be halted. The predictive validity of the scopolamine model is perhaps the highest in cholinesterase inhibilors. Furthermore, despite a frantic search, no scopolamine trial in humans could be found dem 


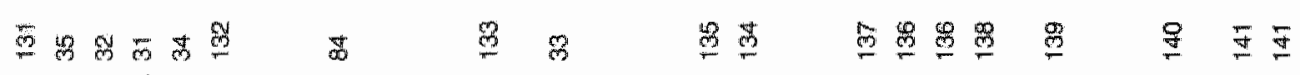

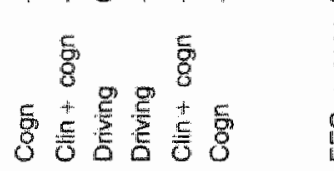

$\stackrel{0}{\overline{8}}$

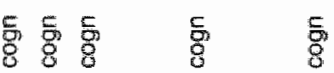

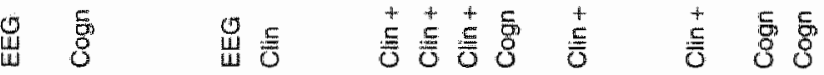
믕

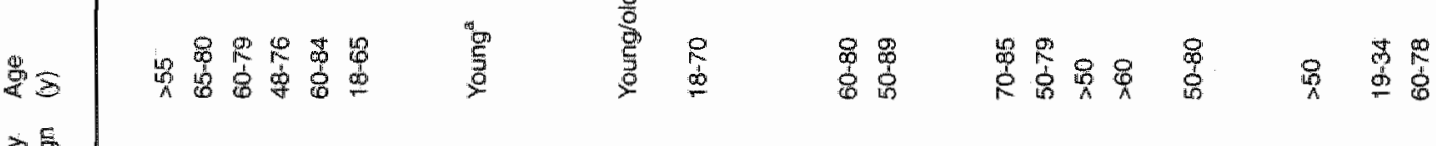

衰要

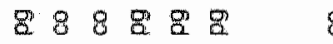

罟 品

몽 용

욜 g g g

g 8 욤

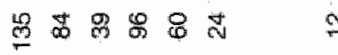

8 \&

용두

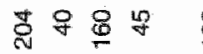

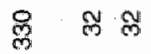

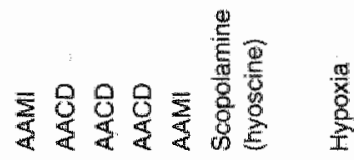

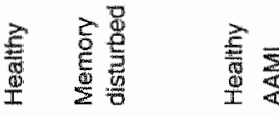

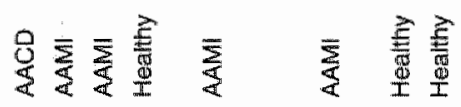

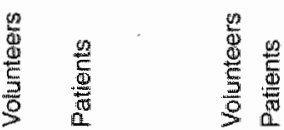

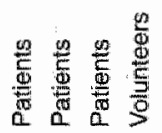

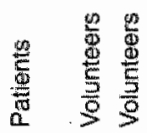

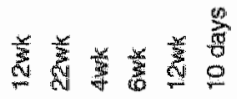

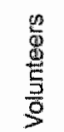

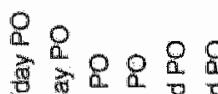

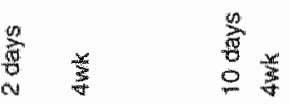

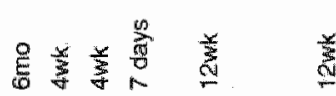

密 को 궁

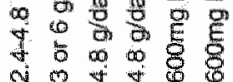

产

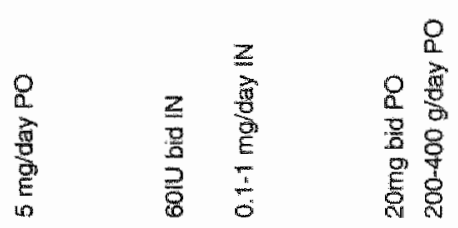

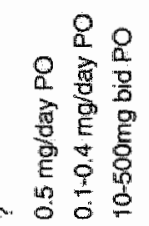

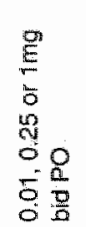

ह

88

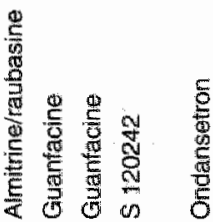

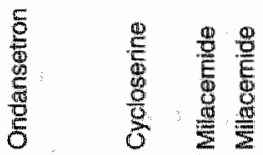

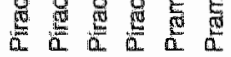
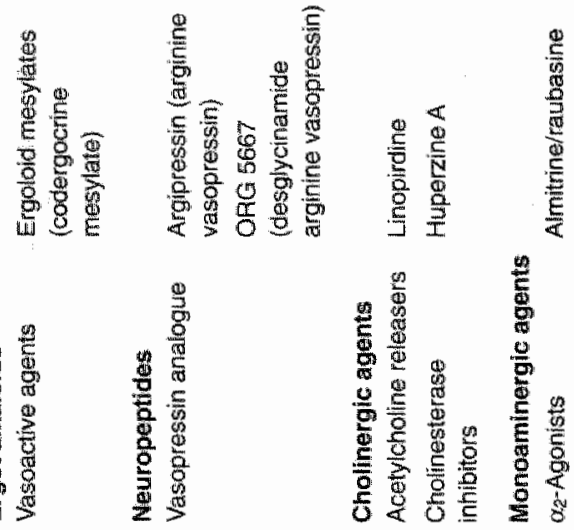

密
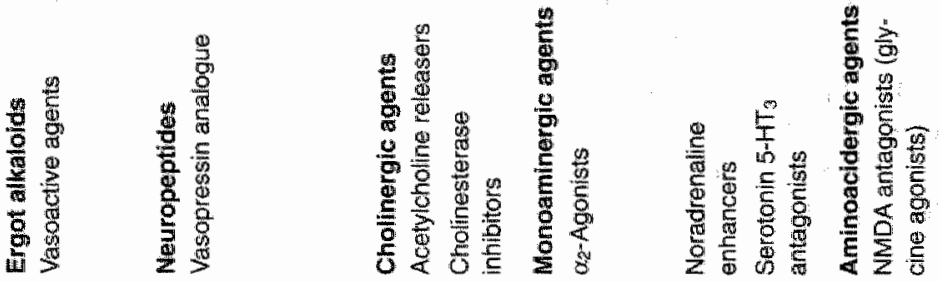


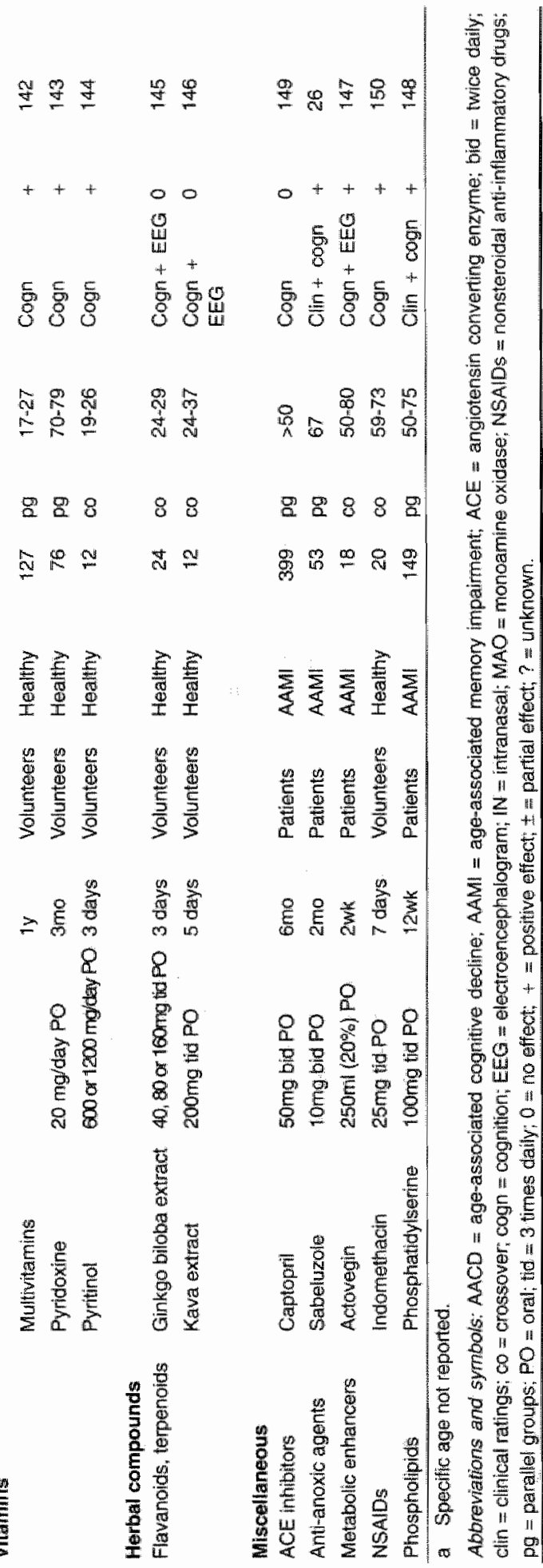

onstrating the cholinergic activity of tacrine. This would have been interesting, since it has repeatedly been claimed that the progress in the search for cognition enhancers is hampered by the lack of an established control drug which is active in the treatment of AACD.

The relevance of studies into the cognition enhancing potential of nicotine may be further illaminated by the report of an inverse association beween smoking and the incidence of $\mathrm{AD}$ among patients having a family history of dementia, [163] this suggests that nicotine may have a protective role in the aetiology of $\mathrm{AD}$. Furthemore, acute nicotine administration has been shown to impiove attention and speed of information processing in $\mathrm{AD}$ patients. 159.1601 Whether these phenomena also apply to AACD remains to be seen, but the relationship between nicotine and cognition seems to be beyond dispute.

The acute blockade of nicotinic receptors induces cognitive dysfunction in healthy volunteers, ${ }^{[164]}$ the degree of cognitive dysfunction induced by nicotinic blockade appears to be age-related. ${ }^{[65]}$ Very recently, it was reported that nicotine enhances both glutamatergic and cholinergic synaptic transmission and that its mechanism of action is not postsynaptic agonism, but to enhance excitatory transmission by activating presynaptic nicotinic acety lcholine receptors. $[166]$

\subsection{Monoaminergic Enhancers}

Diminished catecholamine function is implicated in dementing illness of the elderly and may also be important in AACD. The positive mnemonic effects of adrenergic agonists in the treatment of memory impairments in aged nonhuman primates and in pativents with Korsakoff's disease have motivated studies of these drugs in persons with AAMI, in which deficient central noradrenergic function is also implicated. ${ }^{|6|}$ It has also been suggested that noradrenaline (norepinephrine) is crucial in certain cognitive functions associated with the frontal lobes, particularly the prevention of distractability by irrelevant stimuli. $[167,168]$ 
There is some evidence that serotonin exerts an inhibitory influence on learning and memory and also that changes in the serotonin system accur with aging. ${ }^{[69]}$ Cognitive improvement during therapy with serotonin reuptake inhibitor antidepressants, particularly when administered to elderly patients who are cognitively impaired and depressed, are a topic of current interest that we chose not to address in this paper. Specific interest goes to serotonin $5-\mathrm{HT}_{3}$ antagonists, compounds that have, among other applications, specifically been targeted as cognition enhancers. ${ }^{\text {[70] }}$

Inhibitors of monoamine oxidase (MAO) and catechol-O-methyltransferase (COMT) have specifically been considered for their cognition enhancing properties in neurodegeneration. $[171,172]$

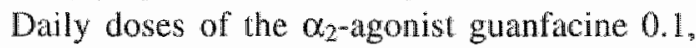
$0.2,0.4 \mathrm{mg}$ or $0.5 \mathrm{mg}$ were administered during a 4-week period to groups of 40 and 160 elderly people who met AAMI criteria. The data suggested that guanfacine may have modest mood-improving effects but had no significant effects on learning and memory. ${ }^{[1.36]}$

Almitrine/raubasine (almitrine bismesilate $30 \mathrm{mg}$ plus raubasine $10 \mathrm{mg}$ ) was administered twice daily during a 6-month period to 155 elderly patients reporting cognitive disorders and displaying an objective cognitive impairment. Evaluations included a visual analogical self-rating scale and psychometric tests. Statistical analysis did not show any significant difference between the almitrine/raubasine and placebo groups concerning changes in assessment criteria from baseline to treatment. However, post hoc division of the patient groups into qualitatively different subgroups according to baseline data, followed by statistical re-analysis, led to the erroneous suggestion that almitrine/raubasine enhanced concentrated attention in patients with mild to moderate impairment of this function. $[137]$

A clinical trial in which the serotonin $5-\mathrm{HT}_{3}$ antagonist ondansetron in doses of $0.01,0.25$ or $1.0 \mathrm{mg}$ was administered twice daily during a 12 week period to 198 elderiy patients with AAMI showed significant improvements in some tests of memory performance after ondansetron $0.25 \mathrm{~m}$ compared with placebo. ${ }^{[39]}$

Although theoretically there would have beel much to be expected from monoaminergic stimu lants, the clinical evidence is generally weak. Thu assertion that the noradrenergic system appears it be involved in the focusing of attention, "167] woul bear relevance for AACD. Focuised attention, a measured by the Stroop effect, was shown to be on of the most sensitive cognitive functions to declins with advancing age. $[173]$ Unfortunately, none of the reviewed studies included such a test, but focusec on memory instead.

It is not very likely that dexamphetamine wil be applied in large scale trials, but the result which showed that a low dose of the general catechol aminergic stimulant dexamphetamine could act as a cognitive enhancer, without adverse effects, 1106 could have some impact as to new developments with this category of substances.

MAO type- $B$ inhibitors have been considered as therapentic agents for $\mathrm{AD}^{1741}$ and as nonspecific cognitive enhancers, $\mid 175 \|$ but application as stimulants appears to have failed. $1102 \mid$ The finding that a MAO type $-\mathrm{A}$ inhibitor, moclobemide, attenuated scopolamine-induced cognitive dysfunction ${ }^{[100]}$ may indicate that this substance increases cholinergic neurotransmission and hence may have a multi-neurotransmitter effect, since its primary mode of action is increasing the circulating levels of noradrenaline and serotonin. Although there are many studies on the cognitive effects of these drugs in depressed patients, these agents have not yet been investigated primarily for their effects in AACD, but perhaps may be suited for use in patients with a combination of $A A C D$ and depression in old age.

The theory of indirect cholinergic facilitation by serotonin $5-\mathrm{HT}_{3}$ antagonists is very well described and seems to explain the positive results obtained in their application with the scopolamine model of cognitive dysfunction and also in AMII ${ }^{108,139]}$ Their additional anxiolytic potential perhaps calls for application to another subclass of AACD. A de- 
finitive positive conclusion is difficult, however, after only one clinical trial.

\subsection{GABA-ergic Agents}

Benzodiazepines, the best known anxiolytics and hypnotics of the past 3 decades, act as agonists at the GABA-benzodiazepine receptor complex. Flumazenil is an antagonist and can hence completely and immediately stop the action of a benzodiazepine. Another class of drugs, the $\beta$-carbolines, also have affinity for the GABA-benzodiazepine receptor complex and act as inverse agonists, antagonists or partial inverse agonist/antagonists.

It has been hypothesised that if sleepiness is associated with increased levels of some kind of endogenous benzodiazepine ligand, the antagonism of flumazenil would immediately 'wake up' a sleeping or sleepy person and hence maintain vigilance. ${ }^{176]}$ An attempt to test the vigilance enhancing properties of flumazenil in sleep-deprived patients showed that this effect, if it existed at all, was very transient and was immediately followed by a vigilance decrement. ${ }^{[177]}$ Nevertheless, flumazenil remains an interesting substance, particularly from a theoretical point of view relating to models of amnesia and because of its highly specific pharmacological action. ${ }^{[50]}$

$\beta$-Carbolines with antagonist or partial inverse agonist properties at the GABA-benzodiazepine receptor complex have been hypothesised to possess the property of disinhibiting cholinergic neurons of the basal forebrain. ${ }^{[57]}$ This hypothesis was tested in humans, by means of the intravenous administration of the $\beta$-carboline ZK 934260.04 $\mathrm{mg} / \mathrm{kg}$ or placebo, after pretreatment with scopolamine. ${ }^{[113]}$ ZK 93426 did not improve the scopolamine-induced memory deficit and thus cholinergic stimulation by $\beta$-carbolines could not be demonstrated in humans.

\subsection{Aminoacidergic Agents}

Age-related changes in NMDA receptors have been found in cortical areas and in the hippocampus of many species. On the basis of a variety of experimental observations, it has been suggested that the decrease in NMDA receptor density might be one of the causative factors of the cognitive decline which occurs with aging. Based on these findings, several strategies have been developed to improve cognition by compensating for these NMDA receptor deficits.

The glutamate NMDA receptor can be modulated by glycine. Under appropriate conditions, stimulation by the amino acid glutamate results in long term potentiation (LTP) of future neural stimuli. ${ }^{[1781}$ The most promising approaches are the indirect activation of glutamatergic neurotransmission by agonists of the glycine site or the restoration of the age-related deficit of receptor density by several nootropic drugs. ${ }^{[179]}$

Millacemide and cycloserine are 2 drugs which stimulate the strychnine-insensitive glycine binding site and hence might facilitate NMDA-mediated neural transmission. Milacemide was administered in doses of $1200 \mathrm{mg}$ on 2 consecutive days to 32 young and 32 elderly volunteers. Relative to placebo, milacemide facilitated the speed and quality of retrieval of learned words. ${ }^{[141]}$ The efficacy of cycloserine 1,5 and $15 \mathrm{mg}$ administered twice daily was investigated in 340 patients with AAMI using computerised assessments of memory and attention. The results only showed nonsignificant. trends of improvement. ${ }^{[140]}$

It has been demonstrated that NMDA antagonists are active in humans, but one of these studies ${ }^{[17]}$ provided the only negative result in this review: a putative cognition enhancer, milacemide, producing cognitive impairment. This could be explained by the potential neurotoxicity of this type of substance, but could also be explained by the hepatotoxicity of the drug. The problem of neurotoxicity could have been overcome with cycloserine, ${ }^{114]}$ a partial agonist/antagonist of NMDA. Furthermore, the clinical trial with cycloserine in AAMI showed some positive effects after 2 weeks of administration, but not at 12 weeks. ${ }^{[40]}$ Perhaps tolerance to the intended positive effects of the drug nullified the treatment response. 


\subsection{Methylxanthines}

As early as in 1901, the effects of caffeine on cognition were studied in humans. Improved comprehension and greater speed and accuracy in information processing, particularly evident under conditions of fatigue, were noted. ${ }^{[180]}$ Improved performance on psychological tasks has, since then, frequently been reported after caffeine intake in healthy volunteers, even with doses as low as $32 \mathrm{mg} .1811$

The methylxanthines, caffeine and theophylline, are generally viewed as CNS stimulants, but recently their identification as adenosine $\mathrm{A}_{\mathrm{A}}$ receptor antagonists ${ }^{\lceil\mid 182\rceil}$ has stimulated research into their effects on memory and cognition. A study investigating the effect of age on response to caffeine showed that the stimulant effects of caffeine predominated in young people, whereas the cognition enhancing effects of caffeine were seen in the elderly ${ }^{[183]}$ Adenosine antagonism is assumed to be the most important mechanism for explaining the effects of caffeine on behaviour. ${ }^{[184,185]}$ Potential cognition enhancers include adenosine ${ }_{A}$ antagonists, since inhibitory adenosine ${ }_{A 1}$ receptors have been found on cholinergic terminals in the hippocampus and the cortex. ${ }^{[186]}$

Although many studies have investigated the acute effects of caffeine in single-dose paradigms, controlled studies on the subchronic and chronic use of caffeine are difficult to find. There is however, one very interesting study describing a positive effect of caffeine on cognitive function, including memory. ${ }^{[87]}$ The study involved 7414 people distributed over age groups of about 20,30 , 40,50 and 60 years. A positive linear relationship existed between daily coffee consumption and cognitive performance. Older people appeared to be more susceptible to the performance-improving effects of caffeine than younger people. ${ }^{[187]}$

Although cafleine is widely known as a CNS stimulant, it also seems to be a cognition enhancer. An explanation might be that its adenosine antagonism has a supplementary effect on cholinergic function. That is, it doesn't affect memory in people when they are young and cholinergic function is optimal. When cholinergic dysfunction is induced experimentally or naturally, due to aging, caffeine might exert a positive effect on memory through this system.

It is difficult to imagine a controlled clinical trial with caffeine, but it would be feasible to study the relationship between age, daily caffeine intake and changes thereof, and cognitive function, between and within volunteers. Furthermore, in clinical trials with putative cognition enhancing drugs, one should keep track of the amount and time of daily caffeine consumption. The results could then either be magnified or attenuated after correction for caffeine intake.

\subsection{Vitamins}

Although traditionally it has been assumed that the vast majority of those living in industrialised countries have an adequate micronutrient intake, there is growing interest in the suggestion that an increased vitamin intake may have advantages for at least some people. ${ }^{[142]}$

It has been argued that the first symptoms associated with micronutrient deficiency are psychological. ${ }^{[188]}$ An association was demonstrated between cyanocobalamin (vitamin $B_{12}$ ) blood level and cognitive performance independent of age. ${ }^{[189]}$ Furthermore, short term supplementation with nicotinamide (vitamin $B_{3}$ ) was shown to improve memory. ${ }^{[190]}$ On the other hand, a review of 53 controlled trials in humans ${ }^{191]}$ on the effects of nicotinic acid (niacin), pyridoxine (vitamin $\mathrm{B}_{6}$ ) and multivitamins on mental functions established that virtually all trials showed serious methodological shortcomings. The only positive results were found with very high dosages of pyridoxine combined with magnesium in autistic children.

Positive effects of pyridoxine supplementation ( $20 \mathrm{mg} /$ day for 3 months) in 38 healthy elderly men compared with 38 controls who received placebo and were matched for age, plasma pyridoxal-5phosphate concentration and intelligence score, yielded a modest, but significant, improvement of storage of information in long term memory, but not with respect to the phasic pupil response, an 
index of mental effort. It was suggested that cognitive effects are primarily associated with a certain range of pyridoxine status increment. [143]

Ten times the recommended daily dose of 10 vitamins [retinol (vitamin A) 3334 IU, thiamine $14 \mathrm{mg}$, riboflavin $16 \mathrm{mg}$, pyridoxine $22 \mathrm{~g}$, cyanocobalamin $0.030 \mathrm{mg}$, ascorbic acid $600 \mathrm{mg}$, tocopherol $100 \mathrm{mg}$, folic acid $4 \mathrm{mg}$, biotin $2 \mathrm{mg}$, nicolinamide $180 \mathrm{mg}]$ or placebo was administered to 27 healthy volunteers for 1 year. At the end of the treatment period, there was some evidence of improved attention in women only and, also in women, an association between improved thiamine status and improved cognitive performance. ${ }^{[142]}$

Pyritinol is a synthetic compound containing 2 molecules of pyridoxine joined by a disulphide bridge. Despite this similarity with pyridoxine, pyritinol has no vitamin action but is regarded as an encephalotropic or nootropic compound. Twelve healthy volunteers received pyritinol 600 or 1200 $\mathrm{mg} / \mathrm{day}$ for 3 days. Significant improvements in critical flicker fusion and choice reaction time, but not of memory, were found [144]

The possibility of vitamins as cognition enhancers remains obscure, despite some remarkably well conducted experiments and trials. The case for pyridoxine does not seem to be very strong.

The association of thiamine deficiency with memory dysfunction and cognitive disorders has been related to an impairment of cholinergic activity, ${ }^{1021}$ and this association was shown in humans using the scopolamine model. Thiamine has been advocated for the treatment of cognitive dysfunction and fatigue of central origin (asthenia), prevalent after prolonged physical exercise in endurance athletes ${ }^{[1931}$ but also in aging. ${ }^{[194]}$ It has been suggested that the cognition enhancing potential of thiamine in $\mathrm{AD}$ is equivalent to that of physostigmine and, because of its general lack of adverse effects, would deserve the benefit of the doubt. [125] Whether this is also the case in AACD remains to be demonstrated.

\subsection{Herbal Compounds.}

Currently, herbal compounds known by ancient medicine in the Far East are experiencing growing popularity as cognition enhancers. One such compound is ginkgo biloba exmact. "The main indication of interest is that of "cerebral insufficiency", a condition related to cognitive decline of organic origin. Among the proposed mechanisms of action are the antioxidant effects of flavonoids, ingredients of ginkgo biloba extract.

A review of 40 clinical trials investigating the effect of ginkgo biloba extract has been published. ${ }^{[195]}$ Only 8 clinical trials were judged to be of good quality ${ }^{[196)}$ and these revealed mainly positive effects of ginkgo biloba extract, although most trials did not include cognitive assessments. A comparison was made between the best clinical trials of ginkgo biloba extract and ergoloid mesylates (codergocrine mesylate), and it was concluded that the compounds were of equal efficacy. [195]

More recently, only 1 study has been conducted in which the brain bioaw ailability of 3 days of treatment with ginkgo biloba extract 40,80 and $160 \mathrm{mg}$ 3 times daily was investigated in 24 healthy volunteers ${ }^{[145]}$ No effects were found on cognitive performance but significant changes in EEG patterns were detected, without changes of indices of alentness, indicating the bioavailability of ginkgo biloba.

Another herball compound, kava root extract, was assessed for its effects on recognition memory using an ERP paradigm in 12 healthy volunteers who were administered $200 \mathrm{mg} 3$ times dally over a 5-day period, [146] Although trends towards improvement were reported, no significant effects of kava root extract were seen.

\subsection{Other Compounds}

\subsubsection{Anth-Inflammatory Agents}

Although classically defined inflammation is not a characteristic of the pathologically aging brain, numerous acute phase reactants and immune-related markers have been found. Furthermore, retrospective studies suggest that theumatoid arthritis patients, many of whom could be expected to be taking anti-inflammalory medication, have a lower incidence of $A D$ than the general population. This has led to the hypothesis that anti- 
inflammatory agents might be effective as cognition enhancers.

Anti-inflammatory drugs may have neurotoxic properties, suggesting that they cross the bloodbrain barrier. The nonsteroidal anti-inflammatory drug (NSAID) indomethacin has been shown in a very small controlled clinical trial to exert some protective effects on cognitive decline in patients with mild to moderate AD. $\| 197]$

Indomethacin $25 \mathrm{mg}$ was administered 3 times daily to 20 healthy elderly volunteers during an 8-day period. Arousal, attention, integration, coordination, memory and mood were investigated using a battery of psychomotor tests and clinical ratings. Assessments were performed before and after the first and last doses. While critical flicker fusion threshold significantly decreased after the first dose, a beneficial effect on choice reaction time latency was seen both after acute and continuing administration of indomethacin. No change was seen in performance on the symbol-digit substitution test, the continuous attention task and in anxiety and depression scores. Cognition may improve in healthy volunteers following indomethacin administration, whereas attention and psychomotor speed remained unaffected. [150]

\subsubsection{Anti-Anoxic Agents}

Anti-anoxic agents protect against hypoxia and ischaemia by improving brain metabolism. Sabeluzole $10 \mathrm{ng}$ or placebo was administered twice a day during a 2 -month period 1053 elderly patients complaining spontaneously about their memory. They were selected if they fulfilled the AAMI-criteria and if they were poor performers on a Selective Reminding Procedure (SRP). No significant sabeluzole-placebo difference was found. However, significant improvements in learning, memory (but not on the SRP) and verbal fluency were found within the sabeluzole treatment group. ${ }^{26 \mid}$ This within-group effect could be an indication of a genuine treatment effect that did not emerge in the between-group analysis because of the small sample size and short treatment period.

\subsubsection{Phosphollipids}

Phosphatidylserine $100 \mathrm{mg}$ administered 3 time daily during a 12 -week period to 149 AAMI pa tients led to significant improvements relative t placebo on performance tests related to learnin and memory tasks of daily life. The investigator reported that analysis of clinical subgroups sug gested that persons within the sample who per formed at a relatively low level prior to treatmen were most likely to respond to phosphatidylserine Within this subgroup, there was improvement of both computerised and standard neuropsychologi cal performance tests, and also on clinical globa ratings of improvement. ${ }^{[148]}$

Again this is an example of post hoc split-hal evaluation on the basis of observed data, an unac ceptable way of analysing and interpreting data rendering the conclusion drawn by the authors, "in terms of the treatment being a promising one fo this indication, less likely.

\subsubsection{Metabolic Enhancers}

Actovegin is a protein-free metabolically activ haemoderivative which improves oxygen and glu cose utilisation. The psychotropic effects of $250 \mathrm{~m}$ actovegin $20 \%$ were investigated in 18 patient: with AAMI during a period of 2 weeks. Pharmaco dynamic evaluations were carried out after the ad ministration of a single intravenous infusion on day 1 , and before and after an additional superimposec infusion on day 15.

EEG brain mapping demonstrated that acto. vegin improved vigilance accompanied by im. proved cognitive performance, increased physio. logical arousal and increased $\mathrm{P} 300$ amplitude. This confirmed the hypothesis that nootropic drugs may influence the P300 amplitude by improving the availability of cognitive processing resources [198 Time-efficacy calculations exhibited more effecl after subacute than acute administration, with the pharmacodynamic maximum after the superimposed dose. [47]

\subsubsection{ACE Inhibitors}

ACE inhibitors have been shown to protect, enhance or restore performance in various learning and memory paradigms in animals. [149.199] These 
drugs may produce their cognitive effects through an indirect action on the cholinergic system. A possible mechanism for the action of ACE inhibitors on the cholinergic system is provided by the find ing that angiotensin-II (the formation of which is prevented by $\mathrm{ACE}$ inhibitors) can inhibit acetylcholine release in in vitro preparations of rodent and human cerebral cortex. ${ }^{[130]}$

Analysis of clinical trials over a treatment period of 6 months with captopril $50 \mathrm{mg}$ administered twice daily to 280 nomotensive patients with AAMI revealed little or no evidence that captopril improved cognitive performance. ${ }^{[49]}$ In a recent review on the effects of $\mathrm{ACE}$ inhibitors on cognitive function, it was concluded that these agents do not have a deleterious effect on cognitive function. ${ }^{[199]}$ No evidence for cognitive improvement by $\mathrm{ACE}$ inhibitors in humans was found.

\subsubsection{Glucose}

The actions of glucose in the brain may be related to the role of the compound as a precursor for the formation of acetylcholine and many other neurotransmitters. The importance of glucose further supports the hypothesis that many cognition enhancing substances produce their effect by means of increased glucose utilisation. ${ }^{\mid 200]}$

The nootropics, amphetamine and vasopressin stimulate the adrenals resulting in peripheral catecholamine release. Subsequently, the liver is in duced to release glucose into the blood. Glucose passes through the blood-brain barrier and increases the availability and uptake of glucose in the brain. This is suggested by the observation that some substances, such as piracetam, aniracetam, pramiracetam, oxiracetam, vasopressin and amphetamine, particularly those that do not cross the blood-brain barrier, are ineffective after adrenalectomy. ${ }^{[00]}$ Furthermore, cognitive function, i.e. learning and memory, is correlated with glucose regulation in aged animals and humans. [200,201]

\section{11.7 Compounds with a Dual Mode of Action}

S 120242 is a compound whose mechanism of action involves facilitation of noradrenergic and vasopressinergic systems. ${ }^{[202]}$ Repeated administration of doses of $S 120242$ in the range of 10 to
$200 \mathrm{mg}$ twice daily were claimed to be capable of correcting $\mathrm{AACD}$ in otherwise healthy elderly volunteers in a dose-dependent fashion. 11381

\section{Discussion}

\subsection{The Patient Population as a Target for Drug Studies}

With respect to the nature of $\mathrm{AACD}$, several remarks can be made. The AAMI concept was well formalised, allowing for the possibility to perform many clinical trials on the same target population. This target population, however, was almost as big as the aging population itself and for that reason, was very heterogenous. One particular aspect of AAMI was the presence of memory complaints. The presence of memory complaints was operationalised as a score on a questionnaire and the 'patient' did not need to have complained about him- or herself. So, in some cases, this population was described as: "elderly people fulfilling the AAMI criteria". The core of the problem is, in our opinion, not so much that cognitive aging, or AACD, is not a disease according to a classic medical model, but the fact that the inevitable consequences of a "natural phenomenon" (aging) is in many cases indistinguishable from the conse. quences of present or past disease states.

Many age effects reported in the literature can be largely explained by suboptimal brain functioning induced by factors other than aging per se. These age-extrinsic factors have been called biological life events (BLE) [203: Examples of BLE are repeated exposure during one's lifetime to: general anaesthesia, organic solvents, neurotrauma and chronic use of psychotropic medications or alcohol. It may be important to discern various subgroups within the heterogeneous group of individuals without dementia but with complaints of impaired cognitive functioning, e.g. those with BLE and those without $14 \mid$

Patient groups for drug studies can be made more homogeneous, which would improve the detection of possible drug effects. The rationale is that the pathogenesis of the cognitive decline can 
be expected to differ for the various subgroups of elderly people with complaints. Examples of this approach are studies investigating the effects of cognition enhancers in patients suffering from the cognitive impaiment due to neurotrauma, $[3,204]$ alcoholic organic brain syndrome, ${ }^{205]}$ epilepsy. [206] organic solvent exposure ${ }^{[207]}$ and hysterectomy. ${ }^{[208]}$

\subsection{Methods Used for Treatment Evaluation}

The use of test batteries covering an array of cognitive functions is seldom explained and therefore one may wonder why so many tests were carried out to assess the answer to one simple question - does this drug enlance cognition? The field suffers from a lack of explicit standardisation, although it has often been specified that this is what is required for the contents of a cognitive test battery applied for drug testing $[209,210]$

The best approach is, in our opinion, always to use at least 2 assessments of the same cognitive function under conditions of varying task load, or difficulty. In the case of cognition enhancing drugs, the relevant components of a test battery should at least include objective assessments of memory storage and retrieval (immediate and delayed recall, and recognition of learned material), speed of search in short term memory (e.g. according to the Sternberg paradigm), focused attention, divided attention, vigilance and estimates of information processing and psychonotor speed (choice reaction time).

Regarding this problem, research in AD is more advanced because an international standardisation of effect measures (e.g. Alzheimer"s Disease Assessment Scale, CIBIC) has been accomplished, although the specificity and the sensitivity of these measures may be questioned. In the domain of AACD, there is no stuch standardisation. Some good examples exist of cognitive test batteries used in several of the AAMI clinical trials. ${ }^{|211.212|}$ One such test battery was entirely based on the assessment of memory functions, ${ }^{[211]}$ without controlling for levels of alertness or vigilance. The other $\operatorname{cog}$ nitive test battery [212] which has been used in a number of clinical trials and experiments, yields many measures of cognitive speed, while no free recall measures of memory functions are taken.

The best solution would perhaps be to apply tests that assess both memory performance and measures of cognitive speed that have been shown to be sensitive to aging and drug effects, and are applicable within standard clinical neuropsychological assessment. ${ }^{[3,213]}$

Another problem often encountered in using test batteries providing many dependent measures is that of an increased type I error. An often heard criticism is therefore that using a battery of cognitive tests always leads to some kind of a positive result. However, it should be noted that it is a matter of good scientific practice to specify an hypothesis explicitly a prion and fully operationalise these into descriptions of outcome parameters. This allows for distinctions to be made between primary and secondary outcome parameters.

In clinical trials, the former refer to the "intentto-treat' analysis. If these basic scientific rules are adhered to, there is nothing against using a test battery yielding a wide range of dependent measures. In fact, it often yields more information than global measures. ${ }^{[209]}$ Furthermore, it is of interest in the search for cognition enhancers whether hypotheses about the effects of a substance are in any manner specific as to the cognitive functions that are the target of enhancement.

Some distinctions have been made, particularly regarding the specificity of memory enhancement, but if a drug simply claims to enhance cognition, indeed, this is an implicit hypothesis stating that the performance on all tests should be significantly enhanced by the particular treatment. In such a case, compiling all the dependent measures into one very nonspecific, but sometimes sensitive performance index, may be a way to circumvent extensive statistical procedures.

In recent years, some drugs (the aminoacidergic agents) have been developed claiming to enhance long term potentiation (LTP) of memory consolidation. Such an hypothesis lends itself for relatively precise operationalisation. It would not be necessary to observe enhanced performance on all 
but a few dependent measures of cognition measuring precisely the expression of LTP, such as improved recall and recognition of learned material. In fact, the absence of effects on aspects of cognition that are not predicted is a primer in such a case. Whether eventual signilicant improvements are clinically relevant, remains a topic that can simultaneously be dealt with employing clinical rating scales.

With respect to the application of EEG measures, we feel that the application of this technique to demonstrate the brain bioavailability of a substance does not make much sense in relation to a demonstration of its efficacy. This does seem to be the case however, for the application of ERP paradigms such as P300. The latter provides a well defined measure of cognitive processing and as such seems to be a relevant index. If background EEG is changed, i.e. a change in the dominant rhythms in the EEG, this would initially indicate changes in parameters such as arousal, activation and vigilance.

\subsection{Future Possibilities}

One problem that this review has shown is that the many promising results from human models are rarely followed by successful results in large scale clinical trials. In some cases, the models are therefore blamed because of their lack of predictive validity. However, if after demonstrating the cholinergic activity of a substance, it appears that no good clinical results are obtained with it, then perhaps one ought to conclude that the clinical population did not have a cholinergic deficit. In other words, validity of the scopolamine model for assessing the cholinergic activity of a drug seems beyond doubt, but whether it adequately mimics $A A C D$ is a matter of great dispute. ${ }^{[2 / 4]}$

Rather than to do away with these kind of models, it might be a better strategy to devise new human models and refine current ones. In the future, the scopolamine model will probably be replaced by more selective and specific models employing muscarinic $\mathrm{m}_{4}$-antagonists, such as biperiden, ${ }^{[215]}$ and nicotinic antagonists like mecamylamine, [164,165] to model aspects of A.ACD and to test new drugs specifically aimed at improving those aspects of cholinergic transmission. For example, the new selective and specific muscarinic mi-agonists that are currently under investigation for $A D$, should reverse the cognitive deficits in humans induced by scopolamine or biperiden, but not those induced by mecamylamine. If these drugs would not satisfy such hypotheses, they would not be true magonists and hence could as such be discarded. It is also evident that the ultimate demonstration of clinical efficacy of substances in patients are perhaps more important until truly predictive human models are established. The value of human models is that they are of help to find out if drugs really do what they claim to do in humans.

Regarding the benzodiazepine model of amnesia, the possible refinement of this model has already been mentioned. When patients were pretreated with the specific benzodiazepine receptor antagonist, tlumazenil, the sedative and attentional effects of diazepam were blocked, but a marked impairment in episodic memory still occurred. This selective pattern of cognitive dysfunction may serve as a model for clinical cognitive syndromes. $[112,216,217]$

A variation of the hypoxia model is that of byperventilation-induced cognitive dysfunction. This model has previously been shown to be more valid for the simulation of ischaemic events in the brain than the hypoxia model and allso that it is a sensitive model to test the neuroprotective effects of nootropic drugs such as aniracetam. ${ }^{[601}$ Recently, hyperventilation-induced cognitive dysfunction was demonstrated employing a variety of cognitive tests. [218]

In principle, models of cognitive dysfunction are pharmacological, physiological or psychologi cal conditions, known to cause cognitive dystunction. In this review we have seen several relatively little used applications such as acute atcohol intoxication and sleep deprivation. ${ }^{[64]}$ Many more of those models exist (for example, all those in which the availability of resources for cognitive processing are manipulated) and could be tried for the 
screening of cognition enhancers. Whether or not such models have direct relevance for the aetiology of $\mathrm{AACD}$ is not the most important question. As long as it is not entirely clear what a drug does in terms of biological and pharmacological modes of action, behavioural models in humans may supply the evidence to the clamed effect of cognition enhancement.

\section{Concluding Remarks}

In general, it can be concluded that there are many active substances that have been shown to be capable of enhancing cognition in individuals without dementia. The question as to the reliable demonstration of clinical efficacy of cognition enhancers in AACD however, is still difficult to answer. We deliberately chose to include as many reports of clinical trials as possible, thereby accepting the impossibility to critically comment on some of the findings. The compounds that have been under investigation for many years, such as nootropics, ergot alkaloids, newropeptides, precursors of acetylcholine, monoaminergic enhancers, GABAergic agents, ACE inhibitors and calcium antagonists, do not seem to be of use in AACD.

Recent developments in research with cognition enhancers for the treatment of $\mathrm{AD}$, i.e. chollinesterase inhibitors, muscarinic agonists and multitransmitter substances, also promise new developments in AACD. The data on these substances in individuals without dementia are interesting, but are currently insufficient to predict the benefits and costs of their use in the treatment of AACD. The substances that have been the most promising, as predicted from theory, animal research and human experimental studies, were the compounds aimed at facilitating glutamate or NMDA-mediated neurotransmission and the compounds aimed at indirectly facilitating cholinergic transmission via the antagonism of serotonin $5-\mathrm{HT}_{3}$ receptors. These have been demonstrated to be active in experimental human studies, followed by disappointing results in the clinic.

If a substance can be demonstrated to exert positive effects on cognition in elderly people in a re- liable manner, and if that substance would lack adverse events, it would be of enormous value, regardless of the question whether we know what it does in the human brain or how it works. In Germany and France, piracetam, ergoloid mesylates and ginkgo biloba extract are among the most commonly prescribed drugs. This illustrates that economical, political and sociological factors as well as fear of dementia and expectancy, rather than proof of efficacy, determine prescription. ${ }^{[219]} \mathrm{Caf}$ feine, nicotine and vitamins are examples of substances that are consumed on a large scale, presumably with the primary aim of improving and sustaining concentrations in the body, but the evidence that they might also improve memory and cognition is increasing. There are many more substances which thave cognition enhancing properties, but to a limited extent, rendering them inefilcacious for AACD. The substance that fulfils all prerequisites does not (yet) exist. In the meantime, perhaps this situation will allow researchers and clinicians to agree on the target symptoms and population characteristics of AACD, as well as on standardisation of models and measures of cognition necessary to demonstrate the effects of cognition enhancing drugs.

\section{References}

1. Chaness $\mathbb{N}$, editor. Aging and human performance. Walterloo, Camadan John Wiley \& Sons, 1985

2. Birren JE; Warner Schate $\mathbb{K}$, editors. Handbook of the psyohology of aging. 3rded. New York: Van Nostrand Remhold Compasiny. 1990

3. LaRue A. Aging and Neuropsychologicall Assessment. New York: Plenum Press., 1992

4. Jolles J, Verhey FRI, Riedel WI, at. Cognuve inpatiment in aderly people: predisposing factors and implications for ex. perimental drug studies. Drugs Aging 1995; 7: 459-79

5. Masur DMA, Sluwinski M, Liplon $\mathbb{R B}$, at al. Neuropsychological prediction of danentian and the absence of dementia in healthy elderly persons. Neurology $1994 ; 44: 1427-32$

6. MoEntee WJ Crodk TH. Age-associated memory mpaiment: a role for eatecholamines. Neurology 1990; 40:526-30

7. Pepeu G. Memory disonders: novel treatments, clinical perspective. Life Sci 1994:55:2189-94

8. O"Brien JT, Levy R. Age associated memory impairment. BMJ 1992; $304: 56$

9. Ban TA. Psychophannacology and succesful cerebral aging. Prog Neuropsycla Biol Psychiatry 1994; 19:1-9

10. Michel B. Sambec R, Scotto JC. French recommendations for clinical dug thats in cognitive disorders of the elderly. Int Geriatr Psychiatry 1994; $9: 823-8$ 
11. Frost $W$, Maicre L. The families of cogmition entancers. Pharmacopsychiatry $1.989 ; 2: 54-100$

12. Surter M, Hagan J, Dudchenko P. Behavioral screaning for cognition enhamcers: from indscriminate to valid festing. Part 1 . Psychopharmacology 1992; 107: 144-59

13. Cacabelos R, Nordberg A, Caanano J, et al Molecular strategies for the first generations of antidenentia drugs (1). Tacerine and related compounds. Drugs Today 1994; 30: 295-337

14. Porsolt RD. Strategies in psychopharmacology: cognition enhancers - from anumals to man; conchuding remarks, Pharmacopsychiatry 1990; 23: 99-100

15. Schwartz G, Bisserbe JC, Bradford D, et al. Late clinical testing of cognition entancers: demonstration of efficacy. Pharmacopsychiatry 1990;2:60-2

16. Muller WE, Pedigo NW. Brain aging: a risk factor of newrodegenerative disonders and a target for therapeutic intervenvion. Life Sci 1994: 55: 1975-6

17. Caine ED. Should agingrassociated cognitive decline be included in DSM-IV? I Neuropsychiatry Clin Neurosci 1993: $5: 1-5$

18. Gilurgea CE. The "nootropic" approach to the pharmeology of the integrative activify of the braim. Conditional Retlex 1973; 8: $108-15$

19. Gouliaev AH, Senning A. Piracetam and other structurally related nootropics. Brain Res Brain Res Rev 1994; 19:180-222

20. Sarter $M$, Hagan J, Dudchenko P. Behavioral screening for cog. nition enhancers: from indiscriminate to valid testing: Part II. Psyelnopharmacology 1992; 107: 461-73

21. Giacobini E, Becker R, editor. Alzheiner's disease: therapeutic stratlegies. Basel: Birkhauser Werlag AO, 1994

22. Kral VA. Senescent forgetfulness: benign and malignant. Can Med Assoc J 1962:86:257-60

23. Crook $T$, Bartus RT, Ferris SH, et al. Age-ussociated menory impairment: proposed dingnostic criteria and measures of clinical change. Report of a National Institute of Mental Health work group. Dev Neuropsychol 1986:2:261-76

24. Biack ford RC, LaRue A. Criteria for diagnosing age-associated memory impaimment: proposed inprovements from the ficld. Dew Neuropsycholl 1989; $5: 295-306$

25. Bamford $\mathrm{KA}$, Cane $\mathrm{ED}$. Does "benign senescent forgetfuiness" exist? Clin Geriatr Med 1988:4:897-916

26. Tritsmans L, Clincke G. Peelmarns B. Does AAMI constitute a real disease entity? A placebomeontrolled double-blind study with sabeluzole (RS8735) ain patient population with real memory problems. Drug Dev Res 1990; $20: 473-82$

27. Rosen TJ. "Age-associated memory impairment': a critique. Special issue: cognitive gerontology. Eur Il Cogn Psychol $1990: 2: 275-87$

28. Smith $\mathrm{C}$, Iwnik RJ, Petersen RC, el al Age associatzd memory impaiment diagnosis: problens of rellability aind concerns for terminology. Psychol Aging 1991; 6:551-8

29. Abate $G$, Angeleri Fi, Bartoreli L, et al. Epidemiologic study on the effectiveness and safety of dihydroergocristine in impaired memory and behavional functions in aged humans. Arzneimitielforschung $1992 ; 2: 1417.21$

30. Clincke GH, Tritsmans L, Peelmans B. Long-term follow-ap treatment with sabeluzole in elderly patients with pronounced memory problems of unknown origin. Drug Dev Res 1991; 23: $301-5$

31. Schmidt U, Brendemuh $D$. Engels $\mathbb{K}$, et al. Piracetam in elderly molotists. Phambeopsychiatry $1991,24: 121-6$
32. Riedel WJ. Cognition enhancing drags, cholinergite function and inge-related dechine. Matstrieht: Micuropsych Publishers. 1995

33. Hijman $\mathrm{R}$, Jolles $\mathrm{d}$, Verhoewer WMA al Desglycinamide (Arg(8)-vasopressin in five trimls with memory-disturbed pintients. Hurn Psychopharmacol 1992;7:723.

34. Marin G, Caratti C. Pelufto Fe Placebo-controlled double -blind study of pramimcetan (CL879) in the treatment of eldorly subjects with menary inpairment. Adw Ther 1992:9:136-46

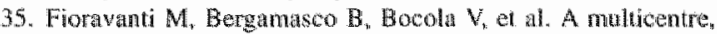
double-bind, controlled study of piracetam ws placebo in ger. tatric patients with nonvascal ar mild moderate inpairment in cognition. New Trends Chin Neuropharnucol 1991; V: 27-34

36. Rai GS, Shovin C, Wesnes KA. A donblemblind, placebo controlled sudy of Ginkgo biloba extract ("anakan") in elderly ouparients with midd to moderate menory impaiment. Curr Med los Opin 1991; $12: 350-5$

37. Gamzu ER, Birkhimer LI, Hoover T, ef al. Early human hidats in the assessment of cognition activators. Pharmacopsychiatry $1990: 2: 44-8$

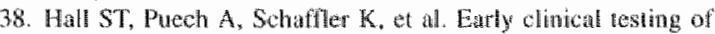
cognition enhalleers: prediction of efficacy. Phiminacopsychatry 1990;2:57-8

39. Porsolt RD. Strategies in psychopharnacology: cognition enhancers - from animals to natn (preface). Pharmucopsychiainy $1990 ; 23: 29-30$

40. Bartus RT, Dean RL, Beer B, al The cholinergic hypothesis of geriatric memory dystinction. Science $1982: 217: 408-17$

41. Bartus RT, Dean RL, Pontecopwo MJ, et al The cholinergic hypothesis: a historical overview, current perspective, and future directions. Ann NY Acad Sci 1985; 444: $332-58$

42. Drachman $D_{w}$ Leswit 1 . Human memory and the cholinergye system: a relationship to anging? Arch Neurol 1974; 30: 113-21

43. Drachman D, Sahakian $B$. The effects of cholinergic agents on human tearning and memory. In: Bareati $A$, Growdon J, Wurt man $R$, editors. Nutrition and the brain. New York: Raven Press, 1979:351-66

44. Kopenan MD. The cholinergic neurothansmitter system in thatman memory and dementia: at review, $\mathrm{O}$ Jxp Psychol $\mathrm{A}$ $1986: 38: 535-73$

45. Kopelmat MD. Com TH. Cholinergic 'blockede' as a model for cholinergic depletion. A comparison of the menory def: cils with those of Alahemer-rype dementit and the alcoholltc Korsakoff syndrome. Brain 1988; 111:1079-110

46. Molchan SE, Marinez RA, Hill J at al Incrodsed cognitive sensitivity to scopolamine with age and a perspective on the scopolanine inotel. Brain Res Rev 1992: 17:215-26

47. Westes $\mathrm{K}$, Warburton DM. Elfects of scopolatime and nicotine on human rapid informaton processing performanes. Psy: chopharnacology 1984; $82: 147.50$

48. Wesnes $K$, Revell A. The sepuathe and combined affects of sebpolamine and micotine on human information processing. Psychopharmacology 1984: 84: 5-11

49. Wesnes $K$, Simpsson PM, Kidd $A$. The uste of as scopolatine model to study the nootropic effects of tenilsetam (CAS 997) in man. Med Soi Res Psychol Psychiatry 1987; 15:1063-4

50. Preston GC, Ward C, Lines CR. el al. Scopolanince and benzodiacepine mode ls of dementia: cross-reversals by Ro $15-1788$ and physostigmine. Psychopharmacology 1989; $98: 487-94$

51. Nuoto E. Psychomotor, physiologicill and cognitive effects of scopolamine and ephedrine in heallhy man. Eur J Chin Pharmacol $1983 ; 24: 60349$ 
52. Schmedte J, Oman CM, Letz re al Eflect of scopolamine and dextromphetamine on human performance. Awiat Space Environ Med 1988:59: 407-10

53. Meador KJ, Loring DW, Lee GP, el al. In wivo probe of central chollinergic systems. J Cerontol 1988; $43:$ M158-62

54. Kennedy RS, Odenhemen RC. Batzey DR, at Differential affects of sonfolam and ampheamine on microconputerbased perfonmance tests. Alat Space Enwiton Med 1990; 61: $6 ! 5-21$

55. Lister RG. The annesic wetion of benzodiazepines in man. Nedrosici Biobehaw Rev $1985 ; 9,87.94$

56. Sarter M, Stephens DN. Beta-carbolines as tooks in memory restetich animil tata and speculations. Psychoptharmat Ser $1988: 6: 230-45$

57. Sarter M, Schneider HH, Stephens DN. Treatrient strategies for senile dementa: arnigonist $\beta$ marbolines. Trends Neurosci $1988 ; 11: 13-7$

58. Lister RG. The offects of benzodiacpines and 5.HT IA agonists on learning and memory. In: Rodgers Ry, Cooper 31 , editors. 5.HT, a Chichester: Wiley, 1991: 26780

59. Bahre MS, Shukint HB. Effects of allifude on mood, behaviour and condivio functioning: a review. Sponts Med 1993; 16 : 97.125

60. Kranier $\mathrm{V}$, Van Huffelen $\mathrm{AC}$, Wheke $\mathrm{GH}$, The hyperventiation-induced ischaemia model in humatu neuropharmacology: neurophysiological and psychometric studies of anirace am and 3-OH aniwcetam. Eur J Clin Pharmacol 1989; 36: 605-11

61. Sallew B, Grumberger J. The hypoxia model in human psychopharmelology: neuropsychological and psychometric studies with aniracetam. Hum Neurobiol $1984 ; 3 ; 171-81$

62. Weindehter $S N_{n}$ Blavet $N_{0}$ O'Donnell RA, et al. Models of iypoxia and cerebral ischemia. Pharmacopsychiatry $1990 ; 2: 94-7$

63. Hindrnarch $I_{\text {. Ker }}$ IS, Sherwood N. The efiects of acohol and other drugs on psychomotor performance and cognitive funcHion. Acohol Alcolyol 1991; $26: 71-9$

64t. Nilsson LG, Bäckman L. Karlsson T, Priming and cued recall

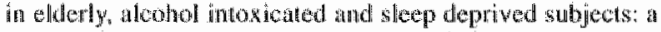
case of functionatly simbill memory deficis. Psychol Med $1989: 19: 423-33$

65. Chusen TG, Wolf J, Cart P. al. The effect of the berzodiazepine antagonist, flumazenil, on psychometric performanec in acute ethand intoxication in mat Eu. J Chin Phanacol 1990. $38: 233-6$

60. Collins WE, Mertens HW, Age, alcohol, and simulated altitude: effects on performance and breathatyzer scores. Aviat Space Binviron Med 1988; $59:$ 1026.33

67. Sanders $A$ to towats a model of stress and human performance. Acta Psychol (Amst) 1983;53:64.97

68. McCani UD, Peneiar DM, Shatham Xe al. Steep deprivation and impaired oogution. Possible role of brair catechold mines. Biol Psychistry 1992; 31: 1082-97

69. Hunt E. What do we need to know about aging? In: Cerella $J$, Rybash J, Hoyer W, et al., editors. Adult information processing: limits on loss. San Diego: Academic Press Inc, 1993: 587.98

70. Hobus P. Expertise van huisartsen. Praktikervarng kennis en diagnosische hypothesevorming. Maastricht: Rijksaniversiteit Limburg, 1904

71. Hyiman R. Desglycinamide-(Arg(8)-vasopressin in pathents with remory disturbances. Utrecht: University Press, 1992
72. Brand Mollos J Learning and tetrie wal rate of words presented asditorly and wisually. I Gen Psycho 1985; 1 2 2:201-10

73. Rey A. L" "examen psychologique dans les cas d"encephalopathie traumatique. Paris: Presses Universitaines da France, 1964

74. Buschke H. Selective reminding for analysis of nemory and Jearning. J Verbal Leaning Verbal Behav 1973: 12:543-50

75. Sterubery $\mathrm{S}$. Memory scanning: mental processes revealed by reaction time experiments. Am Sci 1969;57:421/57

76. Vermagher P, Marcoen A, Goossens L. Facts and fiction abou menory aging: a quantitative integration of research findings J Gerontol 1993; 48: P157.71

77. Brand Nolles I. Information processing in depression and anxiety. Psychol Med 1987; 17: 145-53

78. Saleh B, Anderer P. Kinsperger Ko al. Topographic brain mapping of EEG an neuropsychopharmacology - part II. Clinical applications (pharmaco EEG imaging Methods Find Exp Clin Phamacol 1987:9:385-408

79. Michel CM, Lehminin D. Single dowes of piracetam affect 42 channel event-related potential microstate matps in a cognitive paltudigm. Neuropsychobiology 1993; 28:212 21

80. Wesnes $\mathbb{K A}$. Anand R, Simpson PM, al al The use of a scopolamine model to study the potential nootropic effects of aniacetam and piracetan in healthy wolunters. I Psychopharmacol 1990; 4:219-32

81. Zyhlarz G, Saletu B. Hitzenbenger O, et al. Doublewblind, placebo-controlled, pharmacokmetic and dyatmic studics with two new formalintions of piractum (infusion and syrup) under hypoxis in man. Neuropsychopharmacology 1994; 10:1175

82. Preda $L$. Alberoni M, Bressi $S$, et al. Effects of acute doses of oxiracetam in the scopolarnine model of human ammesia. Psychopharmacology $1993 ; 110: 421-6$

83. Salctu B. Schullz H. Herrmann WM, et al. BMS-181168 for protection of the human brain against hypoxia: double-blind, placebo-controlled EEC mapping studies. Pharmacopsychiatry $1994: 27: 189-97$

84. Salecu $B$, Gunberger J, Anderer $R$. On bratn protection of codergocrine mesylate (Hydergne) agains hypoxic hypoxidosis of different severity: double-blind placebo-controlled quantialuve ESO and psychometrie studies Int I Clin Pharmacol Ther Toxicol 1990; $28: 510-24$

85. Saleu $B_{4}$ Anderer P. Gnaberger J. Topographic buain mapping of EEC after acute application of engotalkaloids in the elderly. Atch Getontol Geriat 1990; 11:1-22

86. Patal A, Klein Mil; Surjus A. di al. RU 41,656 does not reverse the scopolamine-unduced cognitive deficit in bealthy wolum teers. Eur J Clin Pharmacol 1991:41: 225-31

87. Patut $A_{\text {. }}$ Klein MJ ${ }_{\mathrm{s}}$ Surjus $A_{n}$ et al. Study of the potential reversal of triazolam memory and cognitive deficits by $\mathbb{R} U 41656$ in healthy subjects. Psychopharmacol Ben 1991: $104: 75-80$

88. Bruins J, Kumar A. Schneider Helmert D. Influence of desglycinamide-(arg8) wasopressin on memory in thealloy subjects. Neuropsychobiology $1990,23: 82-8$

89. Brains J, Hijman $\mathbb{R}$, Van Ree JM. Effect of a single dose of des-glycinamide-(Arg8/vasopressin or oxytocin on connitive processes in young healthy subjects. Peptides 1992; 13:461-8

90. Siegfried KR. First clinical impressions with an ACTH analog (HOE 427) in the treatment of Alzheimer's disease. Ann NY Acad Sci $199 \%$; 64:0:280-3

91. Wesnes KA, Simpson PM. White $L$, et al. HOE-427, a cholinergically active nemropeptide, improves cognitive effchency in the elderly. Biol Psychiatry 1991; 29:69:1 
92. Molchan SE, Mellow AM, Lawlor BA. al TRH atteruates scopolamine-induced memory impairment un bumans. PSychopharmacology $1990: 100: 84-9$

93. Giue P. Balley I, Wilson $\mathrm{S}$, et al. Thyrotropin-releasing homone selectively reverses loratepsim-induced sedation but not slowing of saccadic eye movements. Life Sci 1992; 50 : P125, 30

94. Wesnes KA, Simpson PM. White $L_{\text {, }}$ en al Chollnesterase inhbition in the scopotanine model of dementia. Arn NY Acid Scil $1991: 640: 268-71$

95. Wallnöfer A, Prescott d, Matek $N$. et al. Physostigmine improwes cognitive perfomance and alters EEC in healhy wot unteers - an approach to study central cholinergic effects. Netropsychopharmacology 1994; 10: $39 \mathrm{~S}$

96. Wesnes KA, Simpson P, Christmas L, el al. Effects of HPO29 in a scopolamine model of ageing and dementia. Ith Congress of C.LN.P. 1990 Sep 9-1.3: Kyoto, 235

97. Lines CR, Ambrose JH. Heald A, et al A double-blind, placobom controlled study of the effects of eptastigmine on scopol amine-induced cogratiwe deficits in healthy male subjects. Hum Psychopharmacol 1993; $8: 271.8$

98. Brass EP. Polinsky R, Sramek JI, et al. Effects of the cholinominetic SDZ ENS-163 on scopolanine-induced cogntive impairment in humans. J Chit Psychopharmacol 1995; 15: $58-62$

99. Rusted J Eaton-Wiliams P. Distinguishing between attentional and annestic effects in information processing: the separatc and combined offects of scopolamine and nicoline on werbat free recall. Psychoptharmacology $1991 ; 104: 363-6$

100. Hindmarch $\mathbb{L}_{4}$ Kerr IS, Sherwood N. Effects of nicothe gim on psychomotor performance in smokers and non-smokers. Psychopharmacology $1990 ; 100: 535-4$ 1

101. Kerr JS. Sherwood N, Hindmarch I: Separate and combined effects of the social drugs on psychomotor perfontance. Psychopharmacology Berl 1991; 104: 113-9

102. Newhouse PA, Penetar DM, Fertig JB, et at. Sitimulant drug effects on performance and behavior after protonged sleep deprivation: a comparison of amphetamine, nicotine, and deprenyl. Mil Psychol 1402; 4:207-33

103. Rusted $\mathrm{J}$, Gratepner $L_{\text {, }}$ O'Connell $N$, el all. Does nicolne improve cognitive ftaction? Fsychopharmacollogy 1994: 115 : 547.9

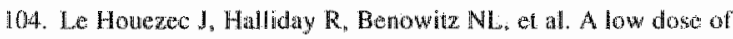
subcutaneoul nicotine irroproves information processing in non-smokers. Psychopharmacology $1994 ; 114: 628$-34

105. Riedel WJ, Hogervorst E, Leboux RLAM, at al Cafleine anen* uates scopolanine-induced memory imparirment in humatis: Psychopharmacology 1995; 122:158-68

106. Soetens. $\mathrm{E}$, D'Hooge R, Huetirg JE. Amphetamine enhances human-memory consolidation. Neurosci Let 1993; 161:9-12

107. Vheent $A$, Risinger $R$, Schmide M. et al. Cognine efiects of idazoxan in normal voltunteers. Nouropsychopharmacology $1.994: 10: 1155$

108. Preston GC, Millson DS, Ceuppens PR, ef al. Effects of the $5 . H T$ receptor atnagonist GR68755 on a scopolamine imduced cognitive defici in healthy sabjects. Br J Clin Pharmacol 1992, 33:546

109. Wesmes K. Anand R. Lorscheid T. Potential of moclobemide to improve cerebral insufficiency identified using a scopol. andine model of aging and dementha. Acta Psychiatr Scand Suppl 1990:360: 71-2

110. Curran HV, Birch B. Differentiating the sedative, psychomotor and amnesic effects of benzodiazepines: a study with mid-

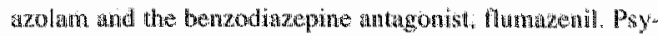
chopharmaon Ber $1991 ; 103: 51923$

11. Ghonein MM, Block RI. Ping ST, et al. The interactions of midazolan and fumazent on human mamory and cognituon. Anesthesiology 1993; 79:1183-92

112. Hommer D, Weingartmer HI, Breter A. Dissociation of benzo-

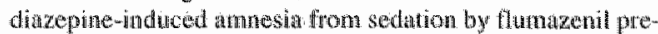
treatment. Psychoplatamacology $1993 ; 112: 455-60$

113. Duka T, Edelmann V, Schutt B, et al. Scopolamine-induced amnesta in humina: lack of effects of the benzodizepine re.

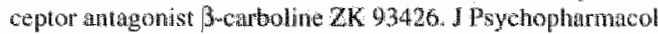
$1992 ; 6: 382-8$

14. Jones RW. Wesnes KA, Kirby J. EAllocis of NMDA modulation in scopolamine dementist. Ann N'Y Acad So 1991; 640:241.44

115. Hesnes $K$, Jones RW, Kinby J, al D-Cyclosen ane andagonizes scopolamine induced menory impairments and improves memory in the elderly. Biol Psychiatry 199;; 29: 7005

116. Wesnes K. Jones RW, Kinby J. Tline effects of D-cyclosentine, a glycine agonisl, in a bumam model of the cognitive deficits associated with ageing and dementia. Br $\mathbb{d}$ Clin Plwamacol $1991: 31: 57 \%-8$

117. Camp-Bruno JA. Herting RL, Wunsberg BG. Milacentide ef: fects on menory and wigitance. Biol Psychisity 1991: 20:286

118. Yn G, Maskray V, Jackson SH, et a l. A comparison of the centrat nerwous system effects of calfeine and theophylline in elderly subjects. Br ll Clin Platmacol $1991 \div 32: 341.5$

119. Matila ME, Matrila MI, Nuoto E. Catrene moderately antagonzes the effects of triazolam and zopichone on the psychomotor performance of henithy subjects. Phamacol Toxicol $1992: 70: 286 \% 9$

120. Hasenfrac M, Bunge $A_{*}$ Dal Pra $G$, et al. Antagonistic eflects of caffeine and alcohol on menfal performance parmmeters. Pharmacol Biochen Belaw 1993; 46: 463-5:

121. Rush CR, Higgins ST, Hughes JR, et al. Acute behtuvion effects of triazolam and cafferne, alone and in combingution, in humans. Exp Clin Psychophatrmacol 1994;2:211-22

122. Lorist MM, Snel I, Kok $A_{n}$ er al. Influence of calfeine on selective attentom in well rested and lattiged subjects. Byohom physiology $1994: 3: 525 \times 34$

123. Loris MM. Snel J, Kok A. Influence of caffentio on information processing stages in well rested and fatged subjects py chophumacology 1994: $113: 41 \| 21$

124. Tiplady $B$, Fagan $D$, Lamont $M_{4}$ et al . A comparison of the CWS eflects of enprofylline and theophylline in healthy sublifects insessed by performance lesting and subjective meatsunes. Br „Clin Phamato $1990 ; 30: 55-61$

125. Meador KI Nichols ME Franke P, et al Evidence for a centat chalinergic effect of high-dosa hiamine. Ann Neurol 1993; 34: $724-6$

26. Benton D, Owens DS. Blood ghocose and human memory. Psychopharmacology $1993 ; 113: 83-8$

127. Rosadin $G$, Stannita WO, Nobill $F$, at Phosphat dylserine: quantitative $\mathrm{EEG}$ effects in healthy volunters. Neturo psyctroblology $1990 ; 24: 42-8$

128. Latd SL, Sommer SA, LaBerge $S$, et al. Ereet of phosphittidylcholine on explicit memory. Clin Neuropharmacol 1993; 16: $540-9$

129. Meyer FP. Influence of mifedipine on human performance fot lowing a single dose - diflerentid psychopharmacological a.spects. Hum Psychopharmacel 1994:9:93-100

130. Lines CR, Preston GC, Dawson CE, et al The effects of preireatment with endtapril mateate gni scopolamine-induced 
cogertive deficils in healthy volunteds. J Psychophanmacol $1991 ; 5: 228.33$

13月. Israet L, Melac M. Milinkewith D, et al Drug therapy and memory waining progratas: a double-blind randomized ural

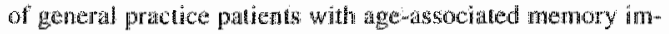
paiment. Int Pychogeriat 1994: 6: 155-70

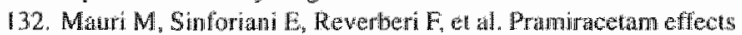
of scopolamine-induced ammesiat in had hy volunteers. Arch Gerontol Geriatr 1994; 18: 133-9

13. Dodt C. Pietrowsky R. Sewing A, et al. Effects of vasopressin on event-reidad potential indicators of cognitive stimulus processing in young and old humans. IGerontol 1994; 19 . M183-8

134. Wang Z-X, Ren Q-Y, Shen Y C. A Double-bind, control study of huperzine $A$ and piracetam in patients with age-fissociated mermory impanment and Alaheimer ${ }^{*}$ s disetsese Neuropsychopharmacology 1994: 10:763S

135. Saletu B, Darrugh A, Bruel HP el al. EEG mapping central effects of multiple doses of linopirine - a cognitive enhancer" in heallhy elderly male subjets. Hum Psychopharmacol $1991 ; 6: 267-75$

136. McEnee W., Crook TH, Jenkyn LR, et al. "Treatment of ageassochated memory imparment with guanfacine. Psychopharmacol Bull 1991; $27: 41.6$

137. Poitrenaud J, Piene $r$, Malbezin $M$, et all. Almitrine-raubasine and cognitive impairment in the elderly: results of a 6 month controlled muticenter study. Clin Neuropharmacol 1990; 13: $100-8$

138. Westnes K, Neuman $\mathrm{E}$, De Wilde HIJ, et al. Pharmacodynmic effects of repeated oral andministration of 4 different doses of $512024-2$ (cognitive enhancer) in 36 healthy elderly wolun teers. Neurobiol Aging 1994: 15: 100

139. Crook TH, Lakin M. Effects of ondansetron in age-associated nemory impairment. Biol Psychiatry 1991; 2: $888-90$

140. Searle \& Co. Mullicenter, randomized, double-blind study of I $\mathrm{mg}, 5 \mathrm{mg}$ and $15 \mathrm{mg}$ b. id. of cycloserine vs placebo in the viotment of mge-associated memory impaument flechnical report. 1997, EC 6-93-02-007

141. Schwartz BL, Hinsuroud S, Herting RL. en al. Glycine prodng fachitutes memory retriosal in humatis. Neurology 1991; 41: $1341 \ldots 3$

142. Benton D. Fordy J, thaller J, The impact of long-tem vitumin supplementation coln cogntive functioning. Psychopharnth cology 1995: 117:298-305

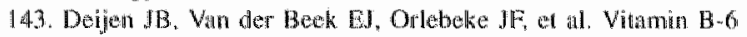
supplanentation in eiderfy men: effects on mood, memory, perfornames and mental effort. Psychopharmaticology 1992 $109: 489.96$

144. Hindmarth I, Coleston DM, Kerr IS. Psychopharmacological effewts of pyritinol in mormal volunteers. Neuropsychobiology $1990 ; 24: 159.64$

145. Kunkel H. EEG profile of three different extractions of ginkgo bilotsa. Nemropysehobiology $1993 ; 27: 40-5$

146. Minte Th" Heinze HI, Marke M, et al. Effect of oxazepara and

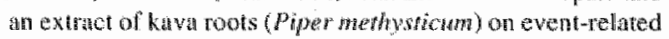
potentials in al word recognirion task. Neuropsychobiology" 1993:27:46-53

147. Saletu B. Gruberger H. Limzmayer $L$ et al. EEG brain mapping and psychometry in age-associated memory imparment affer ackle and 2 -week infusions with the hemoderivative acto vegini double-blind, phesebosontrolled trals. Neuropsychobiology $1990: 24: 135-48$
148. Crook TH. Tinklenberg J, Yenavge J, et al. Eflects of phosphatidylserine in age-associated memory impairment. Nenrology 1991: 41 : 644-9)

149. Sudilowky A, Crook T, Repeti S, at al Angiotensin converting enzyme inhibitor: (ACED) and cognitue functionitg in animals and man. Biol Psychiatry 1991;29:287

150. Brace-Jones $\mathrm{PN}$, Crome $\mathrm{P}$, Kara L. Indomethacin and cognitive function in healthy elderly volumeers. Br J Clin Pharmacol $1994: 38: 45-31$

151. Vernon MW, Sorkin EM. Piracetam: an overview of hts pharmacological properties and a review of its therapentic nse in serile cognitive disorders. Drugs Aging 1991; 1:17-35

152. Mondadori $C$. In search of the mechanism of action of the nootropice: new insights and potential climical implications. Life Sci 192:4:55: 2171-8

153. Stelmach GE, Zalarik HN, Lowe D. The influence of aging and attentional demands on tecovery from postu ral instablity. Aging 1990; $2: 155-61$

154. Teasdate N. Bard C, LaRue J, al. On the cognitive pentrabifity of posiure control. Exp Aging Res 1993; 19: 1 - 13

155. Wadworth AN, Chrisp P. Co-dargocrine mesylate: a review of its pharmacodynamic and pharmacokinevic properties and therapeutic une in age-related cognitive dechne. Drugs Aging 1992:2:153-73

156. Jolles J. Vasopressina and human behavior. In Gash DM, Boer G. editors Vasopressinln, principles and properties. New York: Plemum Press. 1987: 549-78

157. MoEntee WJ, Crook TH. Cholinergic function in the aged brain: implications for treatment of memory imparments associated with aging, Behav Phan macol 1992; $3 ; 32 \%-36$

158. Bodick NC, DeLong AF, Bonate $\mathrm{PL}$ et al. Xanomeline, a specific Ml agonist: early clinical studies. In. Giacobin E, Bec-

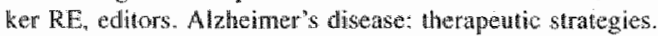
Basel: Birkhäuser Verlag AG, 1994: 234 8

159. Saluakian B. Jones GMM, Levy R. et al. The effects of nicotine on attention. information processing, and shorttrem menory in patents with dementiat of the Alzhener type. Bry Psychatry 1989: 154: $797-800$

160. Jones GMM, Sahakian BI, Levy R, al al. Effects of acule sutb. culaneous nicotine on attention, frformation processing and shon-tern wemory in Alzhemer is disease. Psychopharnatcollogy $1992 ; 108: 485-94$

161. Wagstaff AJ, McTavish D. Tacrine: a review of its phamacodynamic and pharracokinetic properties, and tharapeutic ef. ficacy in Alzheimen's disease. Drugs Aging 1994: 4:510-40

162. Giacobini $\mathbb{E}$, Becker R. Development of drugg for Alzheimer therapy: a decade of progress. In: Giacobini $\mathbb{E}$, Becker RE, editor. Alzheimer"s disease: therapentic strategies. Basel: Bithăuser verlag $A \mathrm{G}, 1994: 1-7$

163. Van Duijn M, Holman A. Relation between nicotime intake and Aldhemer"s disease. BMJ 1991; $302: 1491-4$

164. Newhouse PA, Potret A, Corwin J, et all. Acute nicotinic blockide produces cognitive impairment in nomal humans. Psy chopharmacol Berl 1992; $108: 480-4$

165. Newhouse PA. Potter A, Corwitn I, et al. Age-related effects of vike nicotinic antugonist mecamylamine on cognition and behavior. Neuropsychopharmacology 1994: 10:93-107

166. McGebee $D$. Heath $M$, Gelber $S$, et al. Ninotine enhancement of last excitatory synaptic transmission in CNS by presynapthe receptors. Science $1995 ; 269: 1692-6$

167. Coull J7. Phamacological mamipulations of the $\alpha_{2}$-noradrenergic system: effects on cognition. Drugs Aging 1994; 5: a: 6-26 
168. Robbins T, Everiu B. Arousal systems and attention. In: Gazanga $M$, edifor. The cogntive netroscienos. Cambridge (MA): MTT Press, 1995: 703-20

169. McEntee WJ. Crook TH. Serotonin, menory, and the aging brain. Psychopharmacol Berl 1991 : 103: 143-9

170. Porsolt RD Serotonin: neurotransmitter "a la mode". Report on the Thind International I. T.E.M. - LABO sympositum on strategtes in psychopharmacology. Serotonin: animal models and cinical targets. Phannatopsychiatry $1993 ; 26 ; 20-4$

171. Muller T, Kuhn W, Przuntek H. Therapy with central active catechal-Omethyltransferase (COMT)minhibutors: is addition of monoamine oxidase (MAO)-inhbibors necessary to sow progress of neurodegenerative disorders? I Nenral Transm Gen Sect 1993; 92: 187-95

172. Stoll S, Hafner U, Pohl D, at al. Age-related memory decline and longevity under treatment with selegilline Life Sci 1994 : 55: $2155-63$

173. Houx PJ, Vreeling FW, Jolies I. Stroop interference: aging offocts assessed with the Stropp Color Word Test. Exp Aging Res 1993; 19: $209-24$

174. Thriot PN, Cohen RM, Sunderland T, et al. L-Deprenyl in Alzheimer"s disease. Arch Gen Psyehiatry 1987; 44:427.33

175. Sctaneider LS, Tariot PN, Goldstem B. Then with l-depenyl (selegiline) and relation to abuse liability. Clin Pharmacol Ther 1994:56:750-6

176. Ziegler G, Ludwig L, Fritz G. Effect of the specific benzodiacepine antagonist Ro $15-1788$ on sleep. Pharmacopsychwtry $1986 ; 19: 2001$

177. O"Hanlon JF, Vermeren A. Effects of Ro 15-1788 on the vig ilance pertormance of sleep-deprived men. Hum Psychopharmacol $1988 ; 3: 267-74$

178. Herting RL. Milacemide and other drugs active at gluamate NMDA receptors as potential treatment for dementia. Ann NY Acad Sei 1991; 640: 237-40

179. Muiler WE, Seheuer K, Stoll S. GHhtamenergic treatment sirattegies lor age-related memory disorders. Lifo Sci 1994:55 $2147-53$

180. Makowisch H. Intellectual functions and the bration. An Hivtorical perspective. Seatte: Hogrefe and Huber. 1992

181. Lieberman $H R$, Wurtman $\mathrm{RJ}$, Ende GG, et al. The elfects of low doses of caffeine on human performance and mood. Psychopharmacology $1987,92: 308-12$

182. Biaggioni I, Subir P, Pucket M. et al. Caffeine and theophylline as adenosine receptor antagonists in humans. J Pharmacol Exp Ther 1991:258:588.93

183. Swift $\mathrm{CG}_{\text {, Tiplady }} \mathrm{B}$. The effects of age on the response to calfene. Psychopharmacology $1988 ; 94: 29-31$

184. Stavric B. An update on research with coffee/caffeine 1989 1990). Food Chem Toxicol 1992:30:533-5

185. Nehlig $A$, Daval J-L, Debry G. Caffeine and the central nervons system: mochanisms of action., biochemical, metabolic and psychostimutam effects. Bran Res Rev 1992;17: 139470

186. Briley M. Biochemical strategies in the search for cognition enhancers. Pharmacopsychatry $1990 ; 2: 75-80$

187. Jarris $M$. Does caffeine intake enhance absolute levels of cog ritive perfornance? Psychopharmacology $1993 ; 110: 45-52$

188. Benton D. Vitamin-mineral supplements and intelligence. Proc Nutr Soc 1992; $51: 295-302$

189. Bohnen N, Jolles J, Degenalar CP. Lower blood levels of vilamin $B_{1} 2$ are related io decreased pertiormance of healthy sobjects in the Stroop Color Word Tiest. Neurosei Res Commum 1992 , 11: $53-6$

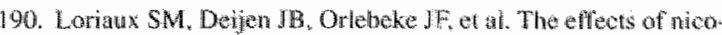

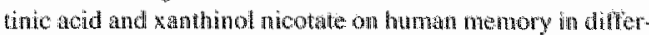

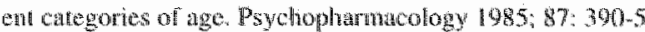

191. Kleijnen J, Kripschid P. Nacir and vitamin $\mathbb{E}_{6}$ in mental funcdionimg: a review of controlled trals in humans. Biof Psychiatry 1991:29:931-41

192. Micheau J, Durkin TP. Destrade C, es al Chronic adminatration of salbutianine improves long term menory fomation in inica: possible cholinergic nediation. Phambel B Bochem Behav 1985:23: $195-8$

193. Consolis $\mathrm{S}$. Mas M. Intertit d'un antiasthenique polywatlent, Arcalion 200 sur la vighance el lo stress des sportifs en haute comperition [in Frencta]. Psycho Med 1988:20:2

194. Israel L. Dell'Acio E. Hugonot R. Arcalion 200 entrimement

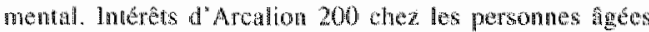
astherniques. Jonirnale de Medecine Printique 1989; Sappl. 19.24

195. Keifnen J. Knipsohild P. Ginkgo biloba for cerebral insulticiency. Br J Clin Pharmacol 1992: 34: 352-8

196. Klejnen J, Knipschild P. Gungo biloba. Lancet 1992, 340 : II. 1360

197. Rogers 1, Kinby LC. Hempenthan SR, et inl. Chnical trial of indomethacin in Alzheimer"s disense. Nenrology 1993; 43 1609-1]

198. Semlitsch HV, Anderer P. Satek B. at. Topographic mapping of cognitive event-related potentiats in a doublowblind, placebo-controlled study with the hemoderivatiwe Actowegin in age-associated namory impaiment. Neturopsychobiology $1990: 24: 49-56$

199. O'Brien AJ, Bulpit CI. The effeets of ACE inllibitors on congnitive function. Drugs Agung 1995; 6: 173-80

200. Wenk GL. An hypothesis on the role of glucose in the mechawism of action of cogentive enthanceas. Psychophanmacology $1989 ; 99: 431-8$

201. Benton D, Singent J. Breakfast, blood gltucose and nemory. Biol Psychol 1092: $33: 207-10$

202. Guez D. Mublberin M. Newman E, et al. SI2024, a new drug in

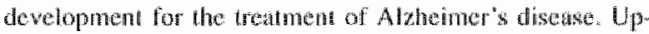
date on abnentia and functional disorders in old aige: 1094 Jul 13-14: London

203. Houx PJ. Vreeling FW, Jollies J. Rigorous hath screning reduces age effect on menory scanting hask. Brain Cogn 1901 : 15: $246-60$

204. Buhner NI, Twijnstra A, Jolles J. A controlled rial willy vaso pressin analogue (DGAVP) on cognitive recowery inmedi-

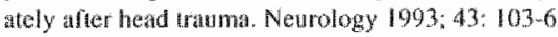

205. Saletu B, Saletu M, Grimberger d, et al. Trestment of the alco-

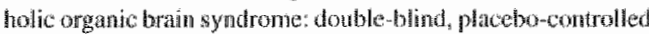
clinical, psychometric and electroc noephalographic mapping studies with modallinil. Neuropychobiology 1993:27:26-30

206. Aldenkamp AP, Wieringen Av Alphens WCl at Doubleblind placebo-controlled. neuropsychological and neuro. physiological invesigations wh oxiraceram (COP $21600 \mathrm{E}$ in memory-impaired paticnts with apillepsy. Neuropsychobiology $1900 ; 24: 90-101$

207. Somnier FE, Ostergard MS. Boysen $G$, ef al. A niracetam lested in chronic psychosyndrome after long-term exposure to or ganic soltwents. A randomized, alouble-blindi, palabeboncontrobled cross-over study with nouropsychological tests. Psychopharnescology 1940; $101: 43-6$ 
208. Phillips SM, Sherwin BB. Efrects of estrogen on memory funchon in surgicully menopalsal onem. Psychoreuroendom crinology $1992 ; 17 ; 485-95$

209. Gathard A. The evaluation of drug effecs in laboratory tasks. In: Hindmarch 1, Aufdembrinke B. On H, editors. Psycho pharnacology and reaction time. Chichester: John Wiley \& Sons: $1988: 15-24$

210. Riedel WI, Hanen HMW, Robbe HWJ, at Automated behavioral testheng in psychotropic drug research. Ir: Mulder LJM. Marse FJ, Sjoww WPB, et al., editors. Conputers tin psychology: applications in ducution. resentreh and psychodingnostics. Anturdam: Swets \& Zeitinger, 1991: 166-70

211. Larrabed GJ, Crook T. A computerized eweryday numory bat. tery for assessing treatment effects. Psychopharmacol Bull $1988 ; 24: 695-7$

212. Simpson PM. Surnon D., Wesnes IKA, et al. The cognitive drug research computerized assessment system for demented pafients: walidation sifudy, lint J Geriat: Psychiadry 1991; 6: $95-102$

213. Jolles J. Aging of brain \& behavior: biomedical, clinical and behavioral tesearch in the doman of aging at the Univarsity of Lumburg. In: Wan Bezoojen CFA, Ravid $\mathbb{R}_{\mathrm{p}}$ Verhofstad AAJ editors. From gene to man. The Hague: J.H. Pasmans Publishers, $1990: 146-50$

214. Rusted 1. Cholinergic blockade and human information processing: are we asking the right gluestions? If Pychophar nacol $1994: 8: 54-9$
215. Salin PR, Granados FD, Galicia PL, at al. Dewelopment of tof erance after repeated adminisiration of a selective muscaring Ma ankgonist biperiden in healtiy human volunteers. Bio Psychiary 1993; 33: 188-93

216. File $\mathrm{SE}$, Goodall $\mathrm{EM}$, Mabbut $\mathrm{PS}$, at al. State-dependent re trieval and midazolam. Hom Psychoplaarm 1993; 8: 243-51

217. Birch $B_{*}$ Curran HY. The differental effects of flumazenil of the psychomotor and annesic actions for midazolam. Psy chopharmacol 1990; 4: 29-34

218. Rother M, Kessler J; Funke M, et al. Memory impairment afte hyperventilation-a physiological model of cognitive dystunc tions. Neurobiol Aging 1994: 15:92

219. Stoppe $\mathrm{G}$, Sandholzer $\mathrm{H}_{\text {, Staed J }}$, et al. Reasons for preseribing cognition enhancers in primary care: results of a repre. sentative survey in Lower Saxony, Germany. Int J Clin Phar macol Ther $1995 ; 33: 486-90$

Correspondence and reprints: Dr W.I. Riedel, Maastrich1 Brain and Behaviour Institute, Department of Psychiatry and Neuropsychology, PO Box 616,6200 MD Maastricht, The Netherlands.

e-mail: Wim.Riedel@NP.RuLimburg. NL 